\title{
A CASE STUDY OF TEACHERS' PERCEPTIONS OF STUDENT ENGAGEMENT IN ONE MIDWEST RURAL HIGH SCHOOL
}

A Dissertation
Presented to
the Faculty of the Graduate School
at the University of Missouri-Columbia
In Partial Fulfillment
of the Requirements for the Degree
Doctor of Education
by
DASHA D. DAVIS
Dr. Carole A. Edmonds, Dissertation Supervisor
JULY 2017


The undersigned, appointed by the dean of the Graduate School, have examined the dissertation entitled

\section{A CASE STUDY OF TEACHERS' PERCEPTIONS OF STUDENT ENGAGEMENT IN ONE MIDWEST RURAL HIGH SCHOOL}

presented by Dasha D. Davis

a candidate for the degree of doctor of education

and hereby certify that, in their opinion, is worthy of acceptance.

Dr. Carole A. Edmonds

Dr. Timothy Wall

Dr. Jennee Gregory

Dr. William Hedge 


\section{ACKNOWLEDGEMENTS}

Wow! I am almost done! Praise the Lord! Thank you, Lord, for helping me finish this doctorate while staying somewhat sane. You know that I had some dark moments where I had to pull from deep inside the perseverance and will to continue and not drop out of the program (especially the first summer). It is almost surreal to me that I am at the point where the only thing I have left to write is the acknowledgements.

I want to give a shout out to my loving husband who thinks I am crazy for all the things that I am always wanting to do, including getting this degree. He has been my rock. He did more than his share of household chores with only a few extra sighs, particularly toward the end when my deadline was approaching. I had procrastinated, so working for eight to fourteen hours a day was routine toward the end. Thank you, Kirk. Thanks to our son, Nathan, who inspires me every day to be the best that I can be, as well as someone of whom he can be proud. Nathan, you can do whatever you set your mind to do with hard work and perseverance.

Thank you to my cohort members who were always there for me when I had questions or just needed to curse a little. I could not have asked for a better group of people to go on this journey with me.

Dr. Edmonds and Dr. Wall, you both were amazing! I learned so much and working with such smart people was an honor. I could not have made it through this program without your insight, feedback, and encouragement.

Thank you to all my co-workers and administrators who have shown such kindness and support through this long process. Thank you to my co-workers and my friends who kept checking on me asking if I was done with my "paper" yet. 


\section{TABLE OF CONTENTS}

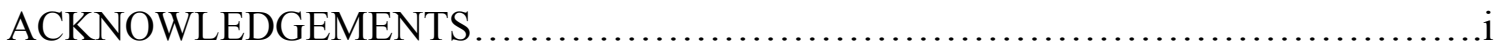

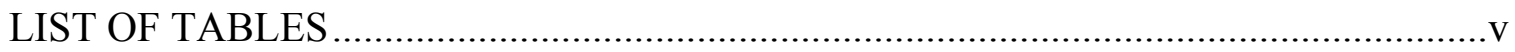

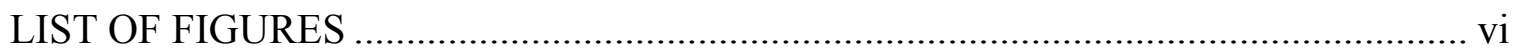

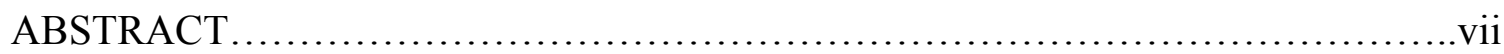

Section

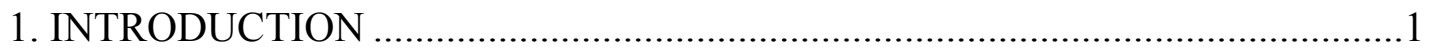

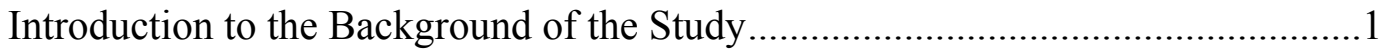

Statement of the Problem.................................................................................

Problem of Practice........................................................ 3

Existing Gap in Literature..............................................

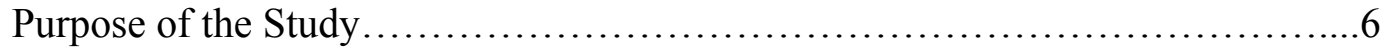

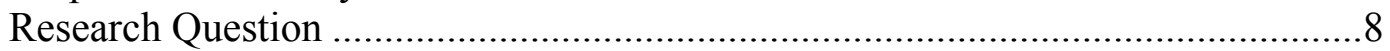

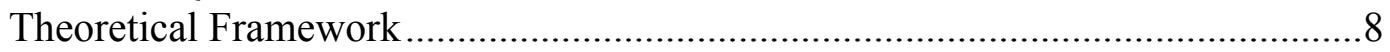

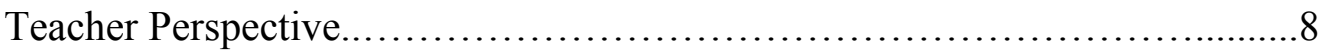

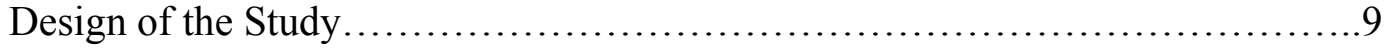

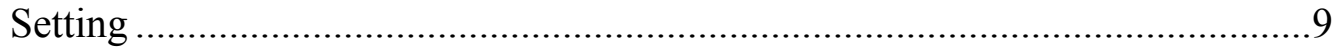

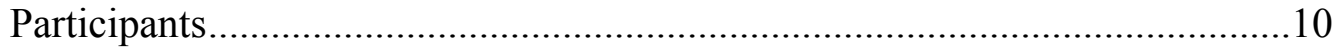

Research Methods and Data Collection ........................................................11

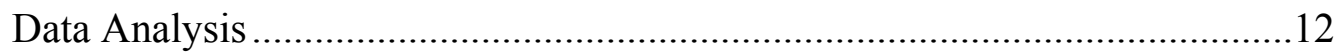

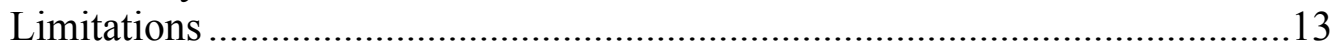

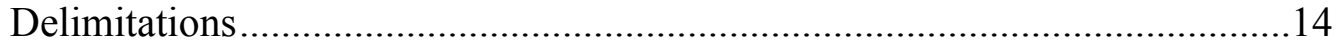

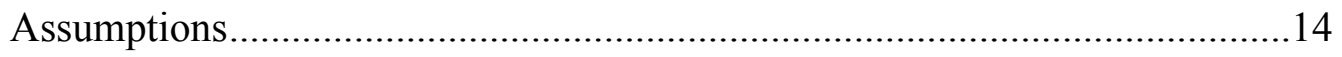

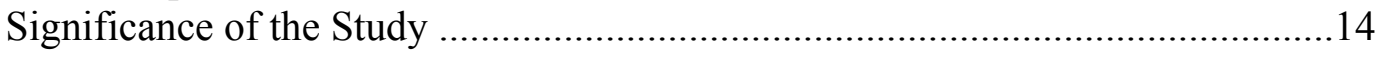

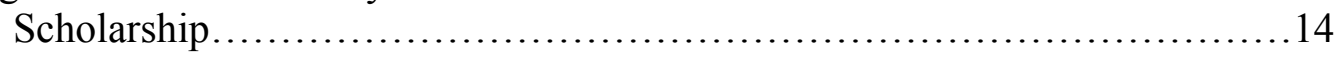

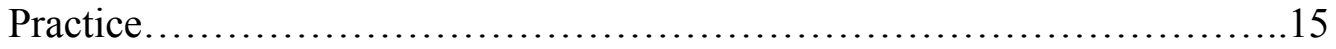

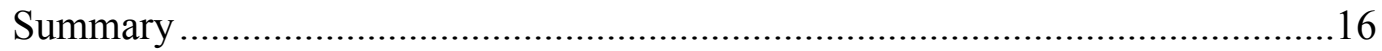

2. PRACTITIONER SETTING FOR THE STUDY ………....................................18

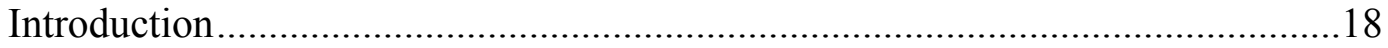

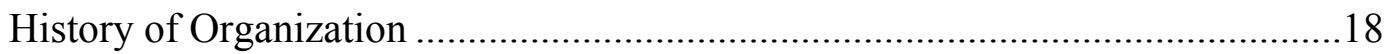

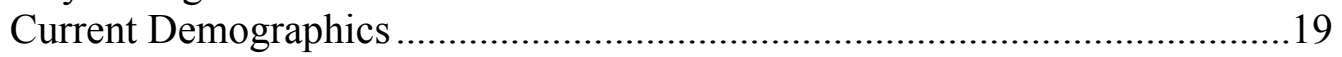

Long-Range Facilities Plan..............................................19

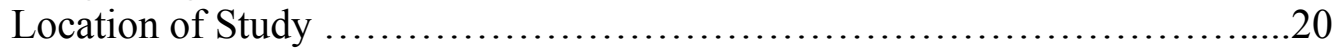

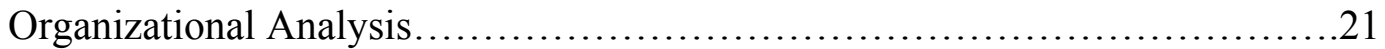

Collaboration and Professional Development.............................22 


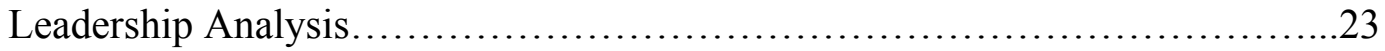

Ethical Leadership.....................................................

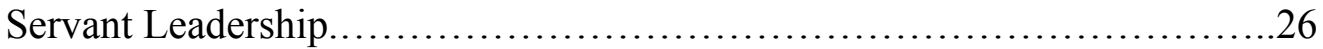

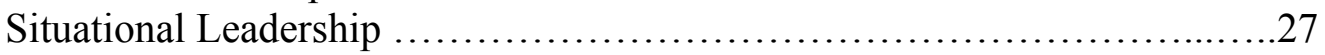

Leadership Evaluation Process..........................................27

Implications for Research in the Practitioner Setting .........................28

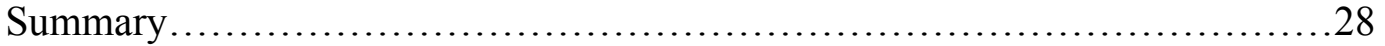

3. SCHOLARLY REVIEW FOR THE STUDY.................................29

Introduction to the Problem................................................29

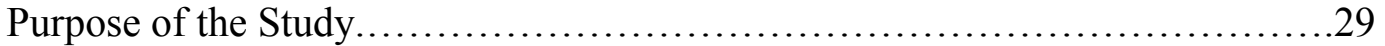

Theoretical Framework-Adult Learning Theory................................ 30

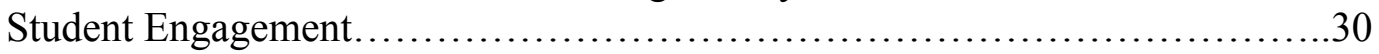

Engagement and Achievement..........................................

Engagement and Age Levels............................................

Teacher Perceptions..................................................... 34

Student Perceptions.................................................... 35

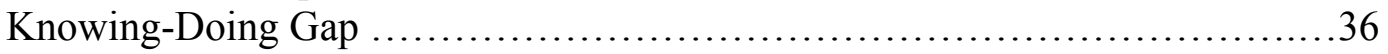

Less Talk More Action...................................................36

Doing Things the Same Way ...............................................

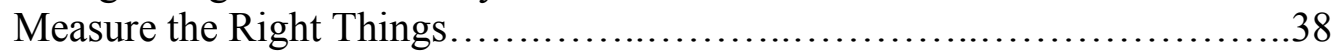

Detrimental Competition.............................................. 38

Knowing Doing Gap in Education.......................................... 39

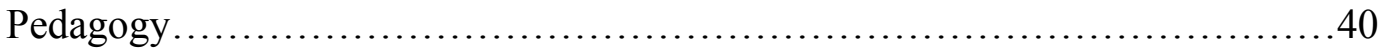

Cooperative Learning .................................................... 41

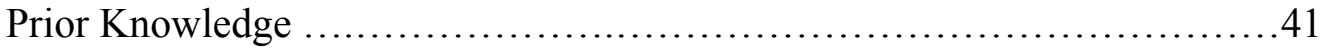

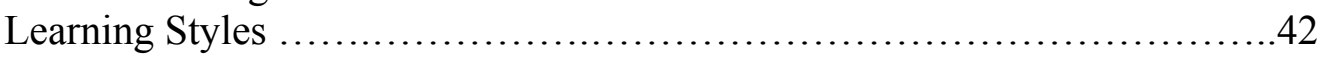

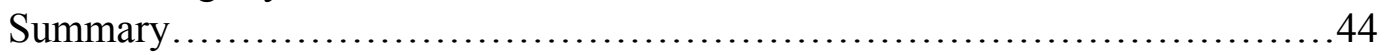

4. CONTRIBUTION TO PRACTICE .........................................45

Practitioner Document.................................................... 46

5. CONTRIBUTION TO SCHOLARSHIP ...................................95

Submission-Ready Journal Article...................................... 96

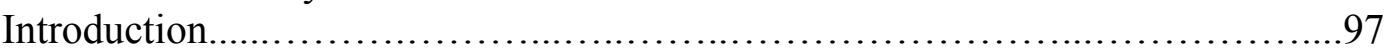

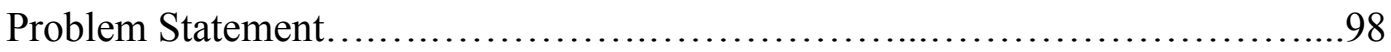

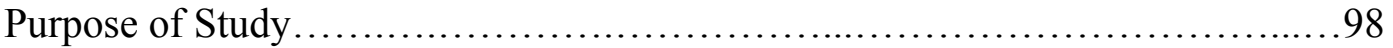

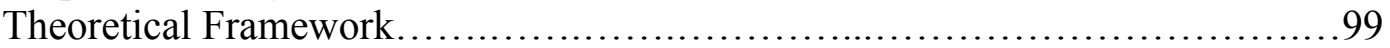

Research Question ................................................... 100

Research Method and Data Collection.......................................100

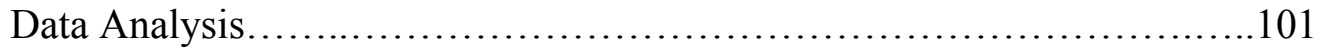

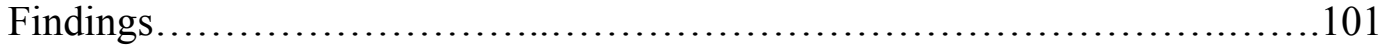

Definition of Student Engagement.................................... 101 
Factors Contributing to Student Engagement.......................... 102

Measures of Student Engagement...................................... 104

Importance of Student Engagement to Student Achievement................. 104

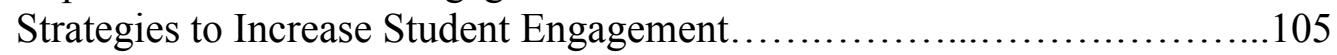

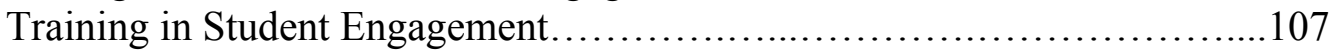

Obstacles to Student Engagement...................................... 107

The Knowing-Doing Gap............................................ 109

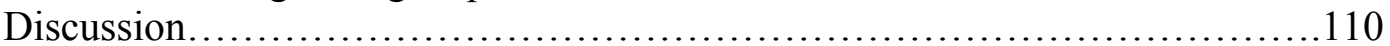

Definition of Engagement............................................ 110

Factors for Student Engagement.................................... 111

Measuring Student Engagement........................................111

Strategies to Increase Student Engagement............................... 112

Teacher Training in Engagement..................................... 113

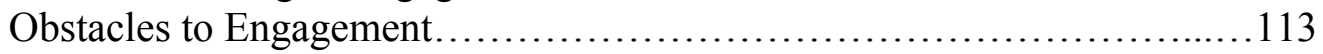

The Knowing-Doing Gap.............................................. 114

Limitations.......................................................... 114

Delimitations.......................................................... 114

Assumptions....................................................... 115

Implications for Future Practices and Research....................... 115

References.......................................................... 117

6. SCHOLARLY PRACTITIONER REFLECTION ............................ 120

Leader............................................................ 120

Scholar............................................................. 123

References......................................................... 126

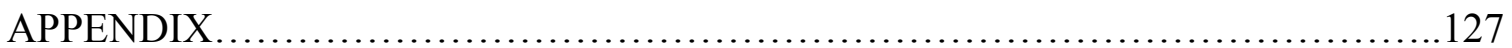

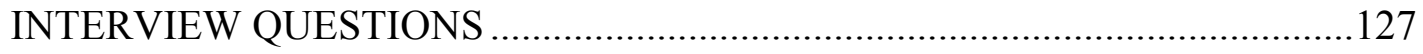

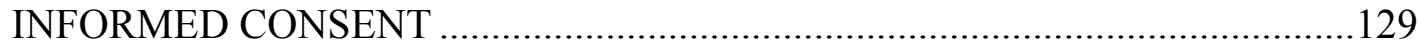

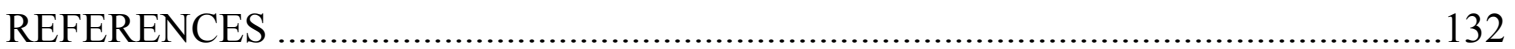

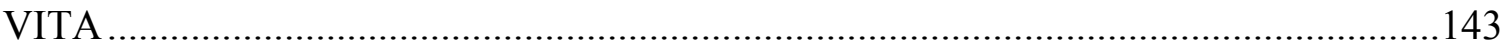




\section{LIST OF TABLES}

\section{TABLE}

1. Table 1 Best Teaching Practices for Auditory, Visual, and Kinesthetic Learners.........................................................4 43 


\section{LIST OF FIGURES}

FIGURE

1. Figure 1 Nateville High School Organizational Structure......................22 


\begin{abstract}
This qualitative study examines teachers' perceptions of student engagement in one Midwest rural high school. The researcher examined teacher, administrator, and members of the regional professional development center responses through interviews regarding engagement definitions, factors, obstacles, importance to achievement, training, strategies, and teacher knowing-doing gap. Definitions of engagement included what students were doing, and what they were thinking in relation to the academic focus. Factors, such as teacher relationships, student interest, and relevance sometimes turned into obstacles if there were poor outcomes of the factors. Themes of strategies included using a variety of teaching practices for all learning styles, and structure or choice of learning activities.
\end{abstract}




\section{SECTION ONE: INTRODUCTION TO THE DISSERTATION IN PRACTICE}

With the myriad of benefits of quality educational systems, there is an everincreasing push for higher standards and achievement for public school students in the United States who score below the top countries on the Programme for International Student Assessment (PISA) tests (OECD, 2016). The purpose and goals of education are multifaceted. Even in Plato's time, he touted that education was a pathway to social and individual justice (Myungjoon, 1994). Sustainable development is one of the focuses for

Finland's school system, which is one of the highest scoring countries in the world on the PISA tests (OECD, 2016). Additional countries that score in the top highest, like Japan, Korea, Canada, Sweden, and Australia are also focusing their educational goals on longterm wellbeing (Hopkins, 2013). Others say that education is to ensure global competitiveness (Key to America's, 2012). Whatever the purpose of a quality education, factors like student engagement, which have been shown to contribute to student achievement (Lee \& Shute, 2009; Antaramian, Huebner, Hills, \& Valois, 2010; Kuh, 2001), must be examined and evaluated as an area of possible improvement to bolster the opportunities for all students to receive a quality education.

\section{Background}

The history of educational legislation will inform the current national motivation for education reform. Until the 1950's, education was state controlled (Kimmelman, 2006). Russia’s launch of Sputnik in 1957 (S. Rep. No. 83-915, 1972) spurred national legislation for America's educational system. This began what is known as the space age and the perception that the former Soviet Union had beat the United States to space. The onus of being second behind the Soviets was placed on the poor American education system (S. Rep. No. 83-915, 1972). The first major federal thrust for education reform 
came one year after Sputnik. The National Defense Education Act (NDEA) introduced additional funding for math and science education (Kimmelman, 2006).

The pressure for education reform did not cease and the Elementary and Secondary Education Act (ESEA) of 1965 was signed into law by Lyndon B. Johnson. This act also funded the Great Society program to provide additional funding to lowincome students and their families (U.S. Department of Education, 2015). Furthermore, the widely-cited report under the Reagan Administration, A Nation at Risk (Gardner \& Others, 1983), placed an urgent call to action for education improvement. These recommendations, along with subsequent and numerous presidential summits, helped create the No Child Left Behind Act (NCLB) of 2001 (Kimmelman, 2006). This NCLB legislation was "designed to improve student achievement and change the culture of America's schools" (U.S. Department of Education, 2003, p. 9). When the graduation rates reached an all-time high of $80 \%$ in 2012, Arne Duncan, former U.S. Secretary of Education, proclaimed “...but even as we celebrate this remarkable achievement, our students have limitless potential, and we owe it to all of the children to work together so they all can achieve at higher levels" (Layten, 2014, par 2). The U. S. Department of Education's Fast Facts (2015) showed graduation rates had improved to $81 \%$ in 2015 from $80 \%$ in 2012 .

Most recently, Race to the Top Act of 2013 provides federal money if states can demonstrate improvement in student achievement by reaching specified benchmarks set forth by this act. One benchmark includes increasing overall achievement, while decreasing achievement gaps among the following subgroups: minorities, students with low socioeconomic status, and students with disabilities. Furthermore, an increase in college enrollment and improvement in effectiveness of teachers and administrators are 
additional benchmarks that school districts must meet (Race to the Top Act, 2013). One way to reach these benchmarks set forth by these initiatives is to examine one factor that has been proven to lead to an increase in student achievement - student engagement.

\section{Statement of Problem}

Research shows that student engagement is one factor that contributes to higher student achievement, particularly within subgroups (Lee \& Shute, 2009; Antaramian, Huebner, Hills, \& Valois, 2010). Lee and Shute (2009) stated:

To achieve academic success, students should be engaged with learning, be able to apply basic learning strategies to grasp the learning material, and be surrounded by positive social-environmental influences that are generated by or obtained from school, peers, and their parents. (p. 6)

Antaramian et al. stated, "students who are more engaged in school tend to have higher grades and better performance on standardized tests" (2010, p. 464). Not only has student engagement been shown to help raise achievement in K-12 schools, but also at the undergraduate level as measured by identified behaviors on the National Survey of Student Engagement (NSSE) as cited by Kuh (2001). Institutional researchers at Indiana University Bloomington, St. Xavier University, University of Montana, and the University of Wisconsin-Green Bay, say the NSSE shows "positive relationships between NSSE results and persistence, as well as academic performance represented by college grade point average (GPA)" (Carini, Kuh, \& Klein, 2006, p. 3).

\section{Problem of Practice}

It is estimated that $40 \%$ of students at the high school level are not engaged with the content or academic activities within the classroom setting (Crotty, 2013). In fact, the number of disengaged students increases as they progress from elementary, middle, and 
high schools (Corso, Bundick, Quaglia, \& Haywood, 2013; Klem \& Connell, 2004;

Eccles \& Wigfield, 2002). In fact, Klem and Connell assert that "by high school as many as $40 \%$ to $60 \%$ of students become chronically disengaged from school" (2004, p. 262).

Low student engagement can lead to numerous negative outcomes. The National Research Council and Institute of Medicine (2004) reports "dropping out of school is for many students the last step in a long process through which students become disengaged from school" (p. 24). Willms states that low student engagement leads to $25 \%$ of students' sense of low belonging, and $20 \%$ of students regularly absent from school (as cited in Harris, 2011). Subgroups of at-risk students, defined by Donnelly (1987) as minority, low-income, and with disabilities, tend to demonstrate lower levels of engagement (Harris, 2011), which may be one factor leading to the widely-documented achievement gap.

The possible negative outcomes of low engagement can have long-term effects outside of school, as well. According to Corso et al. (2013), "Dropping out is highly likely to have serious negative long-term consequences, such as difficulty finding employment and reduced quality of life" (p. 51). Even when employed those without a high school diploma will make $\$ 15,000$ less than the median wage of someone with a high school diploma (Torpey \& Watson, 2014), often plunging them into poverty (Rumberger, 2013). Thornberry, Moore, and Christenson (1985) concluded that drop-outs have more incidences of criminal activity leading to incarceration than peers who did not drop out.

Poverty, incarceration, and poor health are but a few of the detrimental outcomes that often occur to those that drop out of school. To help combat this, researchers from the University of Minnesota implemented a system called Check \& Connect that focuses 
on improving student engagement. Through their research, they learned that engagement played a significant role in whether students dropped out of school (Check \& Connect Student Engagement Intervention, 2016).

\section{Existing Gap in the Literature}

Within existing literature on the area of engagement, therein lies a gap in knowledge. Studies have been conducted in Australia that highlighted research conducted on secondary teachers' perspectives of student engagement (Harris, 2011; Erickson, Brandes, Mitchell \& Mitchell, 2005). Zyngier's research on student engagement is based in Australia, as well $(2008,2011)$. More research from other locales would contribute to the literature in a more comprehensive way. Many teachers view engagement from only the behavioral framework, at the expense of cognitive rigor and emotional engagement (Harris, 2011). Additionally, in one study there was a gap in the preparation of preservice teachers regarding student engagement strategies (Smagorinsky, Wright, Augustine, O’Donnell-Allen, \& Konopak, 2007).

Other studies from Kuh (2001, 2009), McCarthy \& Kuh (2006), Newmann (1992), Zyngier (2008, 2011), Gentilucci (2004) and others have examined engagement through the perspective of students. Kuh's work focuses on the undergraduate level, while Gentilucci's analysis of data is from a study of $6^{\text {th }}$ grade students, with Zyngier focusing on elementary levels. This research will add to the gap in literature of secondary students' engagement through teachers' perspectives.

With much research being done on the student's perspective, fewer studies have been done on engagement through the teacher's perspective. This research will add to the findings of Mitchell and Carbone (2011) who developed a "typology of task characteristics" that lead to student engagement enhancing quality learning based on 
teacher researchers in the Project for Enhancing Effective Learning. Additionally, it will add to the existing research of the Perspective and Voice of the Teacher (PAVOT) project to encourage and spread teacher research efforts (Mitchell, 2000).

Research shows that student engagement involves the time and energy students put forth on a task, and the quality of effort and involvement (Kuh, 2009). However, there is no concise definition of what student engagement looks like in the classroom through teacher descriptions and experiences, nor is there a wealth of knowledge on how teachers can increase engagement in their classroom based on pedagogical strategies through the lens of adult learning. Erickson et al. (2005) say, "teachers are indeed the most critical agents in the process of constructing and nurturing particular types of learning environments in their own classrooms and so their perceptions of their relative success in this regard are important" (2005, p.794). This research will add to the knowledge of teacher perceptions within their classrooms. The discussion and reflection of results of this research will hopefully lead to an increase in knowledge, which is a key component to any teacher's practice, according to Schön's 1987 work in Educating the Reflective Practitioner (Erickson et al. 2005).

\section{Purpose of the Study}

The purpose of this study is to collect and analyze teachers' thoughts and stories on daily student engagement within their classroom. This could include what has worked and what has not worked in hopes of creating a rich and thick description of a multitude of varied and effective strategies concerning student engagement in a rural Midwest high school. This study will provide recommendations for the future as to possible best practices when it comes to students being actively involved in their education, particularly in the high school building of the case study. It is hoped that other high 
schools of similar demographics would also benefit from this study through the generalizability of high school teachers' perspectives on student engagement. From this data, it can be determined if there is a gap between these perceptions and the existing research literature, as studied in the research of Harris (2011) and Smagorinsky et al. (2007).

Teachers' attitudes, along with the ways they think and learn influence students in the classroom. By examining teachers' perspectives on student engagement, the data will provide an opportunity to share and reflect on the many effective ways to engage students. An additional purpose of this research is to help teachers and administrators understand more about how others view and experience student engagement with the desire of meeting (or continuing to meet) the needs of students in a compulsory setting, given all the curriculum standards in the $21^{\text {st }}$ century. The hope of this research is to aid in the reflection process of teachers when preparing, teaching, and adjusting teaching strategies, not just in short-term, but long-term thought processes. This study is not meant to imply causality of teacher behavior and student engagement due to the complex nature and factors involved.

The focus of this research is to increase student engagement in the classroom, therefore, providing students with more educational opportunities to succeed and achieve to the best of their ability. Student engagement increases achievement. Achievement improves graduation rates, achievement gaps, overall achievement, college enrollment, and persistence. 


\section{Research Question}

This case study is designed to answer the following overarching research question:

- What are teachers' perceptions of student engagement in one Midwest rural high school?

\section{Theoretical Framework}

To understand the literature behind this study, the theoretical framework of adult learning theory (andragogy) will be examined. Adult learning theory has been a topic of research for decades. In 1950, Knowles wrote a book called, Informal Adult Education:A Guide for Administrators, that included some of the same concepts as the more recent, Merriam and Bierema's Adult Learning: Linking Theory and Practice (2014). New research continues to build upon the basics of pre-existing research. This research examines the way teachers learn (adult learning theory) about pedagogy, student engagement, and the knowing-doing gap through an adult learning framework. There are some major principles of adult learning that are different than child learning. Merriam

and Bierema (2014) wrote that adult learners have numerous roles and responsibilities in addition to being a student learner. Secondly, adults bring more life experiences into the learning sphere which provides a more robust basis of prior knowledge and context to learning. As a result, the motivations for adult learning vary as the person desires to improve their life, perhaps for a job, personal, or social purposes (Merriam \& Bierema, 2014).

\section{Teacher Perspective}

Viewed within the construct of the education system, one way that adult learning theory is utilized is through teacher professional development and growth. Educators want and need more meaningful, purposeful, and quality professional development that 
not only helps them with their teaching, but also "affirm[s] their practice" (Eldridge, 1998, p. 500). Fullan states that "teachers' jobs are more complex than ever before. They must respond to the needs of a diverse and changing population, a rapidly changing technology in the workplace, and demands for excellence from all segments of society" (Fullan, 1993, p. 5). Obtaining and maintaining this ability to meet multidimensional needs is a complex issue. By understanding adult learning theory, teachers and administrators can use professional development to increase teacher capacity and efficacy not only with student engagement per this study, but other pedagogical strategies that will increase student achievement.

\section{Design of the Study}

The design of this study is emergent, in which the researcher will "learn about the problem" and go into the study with flexibility that the process may change depending on the data gathered (Creswell, 2014, p. 186). This is a bounded case study. Yin defines a case study as "an empirical inquiry that investigates a contemporary phenomenon within its real-life context, especially when the boundaries between phenomenon and context are not clearly evident (as cited in Merriam, 2009, p. 40). This study will be conducted within a bounded system of one high school, in other words, "a single entity, a unit around which there are boundaries" (Merriam, 2009, p. 40). The philosophical perspective in which the study will be conducted is interpretive in that there are multiple realities or perspectives of student engagement, rather than just one reality (Merriam, 2009).

\section{Setting}

The setting of the study is a rural public high school in the Midwestern part of the United States. The researcher is a current teacher within the building in her 17 th year of 
teaching with 13 of those years in the district of study. The school district is a public K12 school in a rural community which, per the school district website, serves approximately 2400 students with approximately 800 students in the high school building where the study is bounded. This is the only high school within the district and receives students from the only middle school. The middle school receives their students from four elementary schools. The student population within the high school is mostly homogenous with little racial or ethnic diversity, including fewer than 20 students of races or ethnicity other than Caucasian. All teachers and administrators are Caucasian. This is typical of the entire district.

\section{Participants}

Participant teachers were chosen through a convenience sampling (Fink, 2013) in which researcher was given permission to interview a variety of certificated staff within a wide range of academic areas. These teachers taught a mixture of subjects: math, English, history, science, physical education, music, and business. Physical education was chosen over art because of the expected higher interaction among students, rather than individual art projects. The researcher's own department was not used for interviews to avoid potential bias in the collection and analysis of the data, furthering the validity of the findings (Krueger \& Casey, 2009). Additional interviews were conducted with both the principal and the vice-principal (two out of three building administrators). A final interview was done with two representatives from the regional professional development center at a nearby university to get expert feedback on current theory and practice at the local level. 


\section{Research Method and Data Collection}

The methods of data collection will be classroom observations, interviews, and a literature review to triangulate the data to ensure validity of findings (Creswell, 2014). Classroom observations were conducted with those teachers who agree to be interviewed, in hopes that some context will be provided with the observation and the interview. The researcher maintained a non-participant role in the observation (Creswell, 2014) and will use the descriptive method of note-taking outlined by Emerson, Fretz, and Shaw (2011), such as “...picturing through concrete sensory details the basic scenes, settings, objects, people, and actions the fieldworker observed" (p. 58). The researcher will take notes on any action, dialogue, and behavior in the classroom. This was conducted in an unstructured way, however, making note on levels of engagement as the focus of the study.

Interviews followed the "questioning route" or analysis sequence described by Krueger and Casey (2009, p. 41) consisting of no more than 10 open-ended questions (Merriam, 2009; Krueger \& Casey, 2009). Questions will be tested for conciseness and clarity with at least two other individuals in the education field (Krueger \& Casey, 2009). Interviews will be no more than 30 minutes to respect the participant's time. Information usually included in a consent form will be provided to participants before interviews and observations explaining the purpose, procedures, risks, benefits, confidentiality, participation, and identification of surveyor (Fink, 2013), as well as notification of the researcher's steps to maintain ethical research standards, per the Institutional Review Board (IRB).

The methodology used for this study is qualitative (Creswell, 2014; Merriam, 2009) in which researcher is the primary data gatherer and uses an inductive process to 
“establish comprehensive themes" (Creswell, 2014, p. 186; Merriam, 2009). Since teachers' experiences and thoughts will be gathered as data, a qualitative focus is the most appropriate as the method centers on the meaning from participants, not the meaning of the author (Creswell, 2014; Merriam, 2009).

Prior to data collection, "a brief proposal will be developed and submitted for review to gatekeepers" for permission and access to the participants and the setting as suggested in Creswell (2014, p. 188), even though informal permission has already been granted by the district superintendent and high school building principal (personal communication, Spring, 2017). Once permission is received to collect data, the results from the open-ended interviews will provide rich description. Additionally, the researcher will write about the results in a rich and descriptive style, adding to the validity of the findings (Creswell, 2014). Interviews were conducted with teachers, administrators, and a local Regional Professional Development Center representative for which a purposeful sample was chosen. Interviews were done individually, with exception of the RPDC who voluntarily paired up, so not to distract the interviewees by the presence of another person, and to protect the privacy of respondents (Fink, 2013).

\section{Data Analysis}

Once interviews are audio recorded, the recordings will be sent to a transcription service. The researcher will check the completed transcriptions for reliability to insure there are no errors made by the transcription service (Krueger \& Casey, 2009). The researcher will provide the transcripts, as well as a preliminary analysis of the data to those interviewed for validation through an accurate interpretation of the interviewees' thoughts and experiences. This process is called member checks (Merriam, 2009) and provides another layer of credibility to the research. Researcher will determine emergent 
themes, then code the themes (Merriam, 2009; Creswell, 2014). Once this process is completed, researcher turns to a deductive process to go back to data to determine if additional literature must be gathered to support themes.

To complete the triangulation of data as a strategy to validate the accuracy of the findings (Creswell, 2014), a literature review will be conducted on the current research that exists on student engagement, pedagogy, and the knowing-doing gap through the lens of the theoretical framework of adult learning theory. Through observations, interviews, and a literature review, the themes that emerge from all three sources will justify and validate the themes.

Special attention will be given to the fact that the research is considered "backyard" research, coined by Glesne \& Peshkin in 1992 (as cited in Creswell, 2014, p. 188) in which the setting is the immediate work environment of the researcher. Steps will be taken to ensure that the process and data are not compromised, and will minimize any risk involved. Multiple strategies for validation will be incorporated into the processes to ensure a reliable and valid outcome (Creswell, 2014).

\section{Limitations}

Limitations to this research study involve the small size of the study, limited time allocated, as well as the time of the school year (last month of school) that the study was done. Additionally, there is a limited generalizability of a qualitative case study (Merriam, 2009). The researcher is a teacher and has many shared experiences inside and outside of the classroom with the participants that were interviewed, and brings personal biases based on experience and education into the interpretation of the findings (Merriam, 2009). Finally, the researcher is a faculty member of the school in the case study, so maintaining positive relationships, as well as employment was essential. 


\section{Delimitations}

The researcher did not interview anyone within the researcher's own department due to potential bias. Additionally, no other schools within the district were chosen as population samples, due to time constraints and easier coordination of scheduling with the researcher's schedule. Finally, only three males were asked to participate in the interviews due to the limited number of male teachers, and the desire of the researcher to interview many different departments — several male teachers were in the same department.

\section{Assumptions}

The researcher assumes the participants were honest and forthcoming with their input with the intention of furthering scholarship, rather than ulterior motives that would skew the data results. Also, it was assumed that all participants were willing participants and felt no obligation to participate in the study. Finally, it is assumed that the participants trusted the researcher to carry out the study with "integrity and competence" (Merriam, 2009, p. 228).

\section{Significance of the Study}

\section{Scholarship}

Educational leaders come in a variety of positions: teachers, instructional coaches, administration, and curriculum directors. The data and analysis concerning student engagement can be used by a variety of educational leaders to train teachers in preservice situations, mentoring programs, and for continuing professional development. Through the framework of adult learning theory, law and policy makers can have a better understanding of the complexities that teachers face as they strive to provide a comprehensive education that meets the needs of the students and of outside 
stakeholders. Fullen states that 'teachers' jobs are more complex than ever before. They must respond to the needs of a diverse and changing student population, a rapidly changing technology in the workplace, and demands for excellence from all segments of society," (as cited in Eldridge, 1998, p. 492).

\section{Practice}

This study will be significant at my institution because the participants in my study will be from this institution. The responses will be applicable to this specific population and will give detailed information about student engagement in this specific environment. Even though the sample size will be small, the study will contribute to the existing studies on teachers' perspectives regarding student engagement. Many small "snap-shots" can add to a bigger picture. This study views student engagement from the teacher's perspective to examine actual practice and outcomes of engagement or lack thereof. Based on the personal experiences of practicing secondary teachers, it can be determined if changes or additional information could be added to pre-service programs or to professional development programs to illicit a continuing reflection and feedback of teaching strategies or behaviors that foster an increase in student engagement.

To obtain additional data regarding student engagement from the student's perspective, which was outside the realm of this study, it is recommended to use the National Survey of Student Engagement distributed to all middle and high school students through district email to gain an extra perspective. Based on future surveys and data from this qualitative study, strategies can be implemented to maximize student engagement, and then measured on a yearly basis. Finally, learning from teachers how they view student engagement hopefully will lead to more dialogue, which would in turn promote a learning culture among faculty and administration, as described in Gill (2010). 
The teacher as learner, "learn[s] from their own experience, their students, and each other" (Eldridge, 1998, p. 492).

\section{Summary}

This research study investigates teachers' perception of what student engagement looks like in their classroom. This will be done through observations, interviews, and a literature review. With these data collection methods, pedagogy, student engagement, and the knowing-doing gap will be examined through the framework of adult learning theory. Reoccurring themes and the rich description of the experiences of educators with student engagement will be identified. Teachers can thoughtfully examine student behavior, as well as teaching methods in hopes of aligning goals to meet the everchanging needs of the students.

Through the triangulation of data from observations, interviews, and a literature review, an analysis can be made on the current perceptions of teachers concerning student engagement at Nateville High School (a pseudonym). This information and conclusions will be shared with not only the building employees, but will be available for all district employees for use in teacher mentoring and professional development. Because of the qualitative nature of the study, it is not meant to be generalized to other settings, but rather specific to this setting and context (Creswell, 2014).

If teachers are continually trying to maximize student engagement, it is possible that students will be more involved and active in their learning. This creates a fruitful and successful learning environment where student attitudes are responsive to the learning process. By equipping teachers, especially beginning teachers, with a plethora of motivational strategies and resources through continued professional development and 
support, students and teachers can maximize the educational experience for successful outcomes. 


\section{SECTION TWO: PRACTITIONER SETTING FOR THE STUDY}

Nateville High School is a microcosm of the Nateville school district within a rural community boundary. To understand the context of this case study, characteristics of each of these environments must be considered. Nateville school district lies within the city limits of Nateville, $\mathrm{MO}$ which claims a $4.4 \%$ unemployment rate (Sperling's Best Places, 2017), compared to 4.8\% national unemployment rate through January 2017 (National Conference of State Legislatures, 2017). Additionally, the median house price for the city is $\$ 98,800$ (Sperling's Best Places, 2017). This socio-economic information for this rural city will provide background for the students within the school district.

Nateville school district is the largest of three Elk County public school districts. Elk County has a population of 17,291 and covers 433 square miles with a population density of 40 people per square mile (U.S. Census Bureau, 2010).

\section{History of the Organization}

Nateville Public School's first commencement was held in 1878 (Alumni Association, 2017) with five women graduates. In 1932, there was a fire that burned down the school, which at the time held grades one through twelve. A new school was built. Nateville School District was reorganized in the 1950s as a response to the Hawkins School Reorganization Act of 1948, calling for a consolidation of rural schools to form more efficient school districts (Alumni Association, 2017).

In 1957, an elementary school was built across town, so the old high school became a junior and senior high school. A new high school was built in 1963, leaving only the junior high students in the 1932 building. This building was torn down in 2010, 
when an additional middle school was built to house $6^{\text {th }}, 7^{\text {th }}$, and $8^{\text {th }}$ grades (Alumni Association, 2017).

\section{Current Demographics}

Additionally, the district has 209 certified staff members (District Report Card, 2017). The enrollment over the last fourteen years has averaged 2345 students, with $93.7 \%$ of students categorized as White. The ethnicities of the remaining $6.3 \%$ of students in the district was "suppressed due to potential low sample size" (District Report Card, 2017). Nateville is an accredited school district in the state of Missouri. The average attendance rate is $91.3 \%$ over the last eight years. The district's average free and reduced lunch rate is $37.5 \%$ over the last five years. Nateville Public School District

currently has seven schools: four elementary schools, one middle school $\left(6^{\text {th }}-8^{\text {th }}\right.$ grades $)$, and one high school.

\section{Long-Range Facilities Plan}

In 2006, the Nateville School District created a plan for long-range facilities as a "planning tool that informs the organization, provides a framework for sound decision making, and enables the school district to effectively anticipate, respond to and manage change" (Long-Range Facilities Plan, 2006). After an assessment of needs by community patrons, administrators, board of education, and school district employees, "new construction, renovation, demolition and general improvement to the physical facilities were recommended" (Long-Range Facilities Plan, 2006). The recommendations were proposed in three phases, starting with a target year of 2007 for completion of the first phase. First phase included building a new middle school, new library at the high school, expansion of existing spaces, additional classrooms, relocation of principal and nurse offices closer to main entrance in two of the elementary schools, as well as safer and 
secure entryways to all buildings. Phase two included creation of a performing arts center at the high school for district and community use and relocation of classrooms and parking lots. Library areas would be expanded at two of the elementary schools with the creation of independent technology labs. Phase three included improvement of athletic seating and accessibility at the high school athletic field. Construction would start during phase three for a new elementary school if an assessment was made during phase two that it was needed. Phase two and three would be completed without an additional tax increase planned, given a target date of 2020 for phase three. At the time of this writing, phase one has been completed and planning has started for the completion of phase two.

In 2009, during the long-range facilities plan implementation, Nateville began a pre-school program for children with special needs. In 2016, Nateville School District received a $\$ 1$ million-dollar community development block grant for early childhood education through the Missouri Start Smart initiative and the Department of Economic Development. The district will build a 7,088-square foot early childhood education center that will educate 80 preschool students (Hall, 2016).

\section{Location of Study}

The location of this study will occur at Nateville High School. This facility was built in 1963 (Long-Range Facilities Plan, 2006). More classrooms were added in 1968, with more additions being built in 1972, 1988, and 2000 (Alumni Association, 2017). In 2000, the community voted to pass a lease-purchase issue on the ballot that provided for the construction of a new science wing at the high school, as well as a new concession stand and restrooms at the high school athletic field. For the reporting year of 2016, the graduation rate was $93.3 \%$. Nateville High School has averaged 740 students in the last 10 years (District Report Card, 2017). 


\section{Organizational Analysis}

The structure of the organization creates a hierarchy of leadership, not only for creating and implementing policies, but also providing the instructional leadership to teachers which directly affects student engagement in the classroom. Nateville School District follows Mintzberg's five basic parts of an organization with a "distinct division of labor" (1979/2005). Mintzberg's model allows for more strategic planning and longterm decision-making from the strategic apex without the distractions of day to day operations that the middle line experiences (Bolman \& Deal, 2008).

This planning and decision-making through the organizational structure are facilitated by aligning with the mission of the district, which is to nurture, inspire, challenge, and encourage every student by providing the education necessary to become a productive member of society (Nateville High School, n.d.). Furthermore, strategic priorities set by the school board (strategic apex), create the framework and goals for the district as it moves forward maximizing the engagement and achievement of the $21^{\text {st }}$ century learner. Nateville's strategic priorities are

- to seek individual student achievement and academic excellence through a challenging curriculum;

- to retain and attract high quality personnel by developing a health and wellness program, increasing professional development and collaboration time, enhancing a teacher mentoring program, enhancing salaries, and developing procedures for collective bargaining;

- to increase and maintain community partnerships by creating a district foundation, developing a means of enhancing community connections, improving community outreach and communication; 
- to provide a high quality learning environment by enhancing facilities, developing a technology plan to meet current and future needs, enhancing safety for students and staff in all the schools;

- fiscal responsibility and revenue generation by finding alternative resources of funding and examining purchasing procedures (Nateville School District, 2015).

The organizational structure provides a framework for all levels of the organization to carry out the mission and goals of the district. The operating core of teachers are the daily facilitators of engagement and student achievement in the classroom and have a direct impact on the strategic goal of academic excellence.

Figure 2.1 Nateville High School Organizational Structure

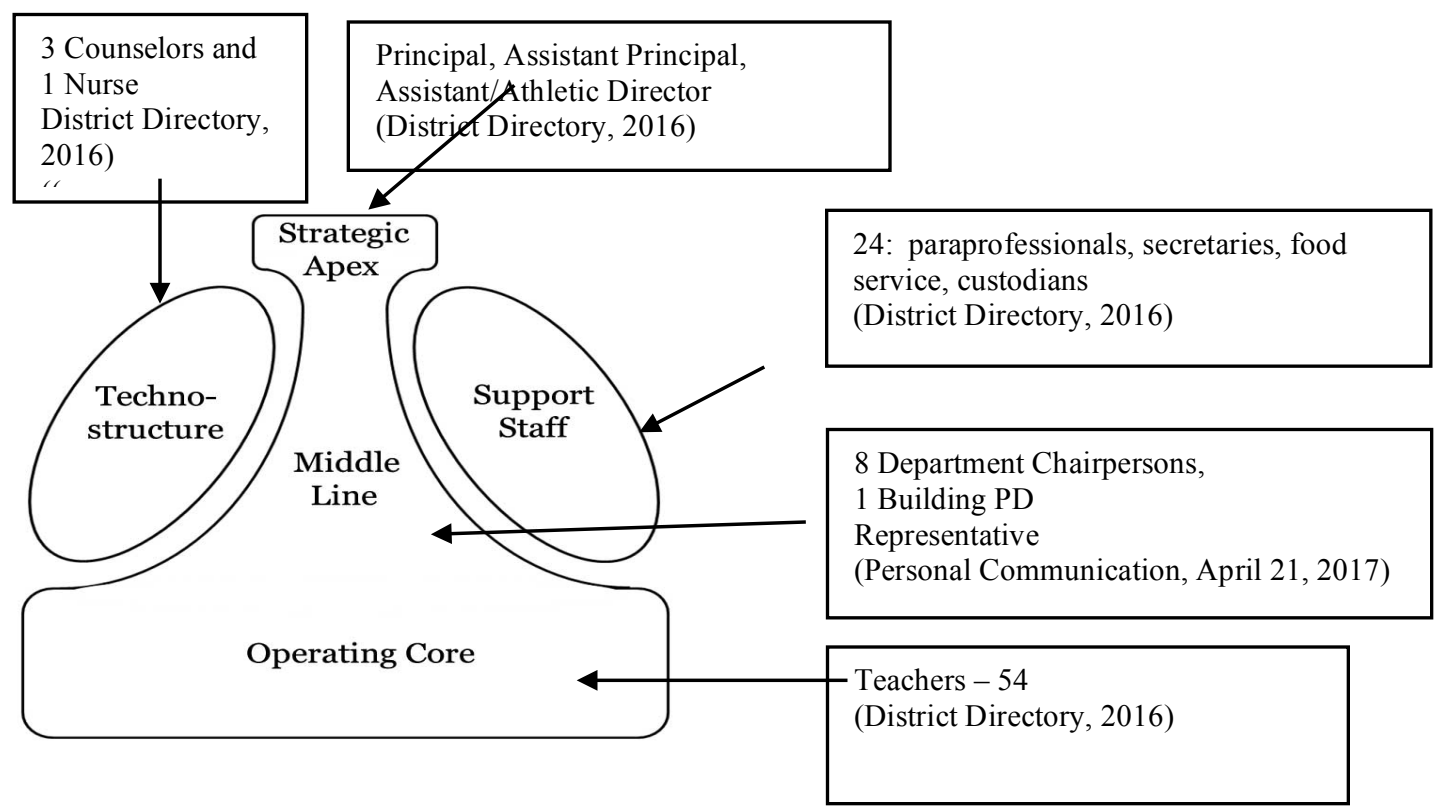

Figure 1 H. Mintzberg, 1979, Reprinted Classics of Organizational Theory, J. Sharfritz, J. Ott, \& Y. Jang (Eds), 2005, p. 220.

\section{Collaboration and Professional Development}

In addition to the division of labor and decision-making hierarchy discussed by Mintzberg, an organization can be analyzed through the interdependencies of the basic 
parts. Thompson (as cited in Mintzberg, 1979/2005) classifies one of the relationships as pooled coupling, in which members in the operating core share resources, but work alone in their own unit. This describes Nateville High School as well as the other school buildings as each teacher shares collective resources, but works independently with their own students.

The high school is in the beginning stages of increasing teacher-leader capacity and collaboration through the creation of department chairpersons for the 2017-2018 school year (personal communication, 2017). Additionally, instructional leadership and idea sharing will be promoted through the start of quarterly professional development newsletter disseminated to the high school faculty that will compile instructional best practices from all departments, as well as summaries or reviews of current educational research (personal communication, 2017). The newsletter will provide follow-up and reflective opportunities from district professional development days in which the focus for the 2017-2018 school year will be the implementation of one to one technology, which could play a major factor in increasing student engagement.

\section{Leadership Analysis}

With the size of Nateville School District, many leadership theories are evidenced in a variety of situations, such as ethical, servant, and situational leadership. Additionally, administrative and teacher leadership can be analyzed using Bolman and Deal's human resource frameworks (2008). Parker and Mayo argue that, "people's skills, attitudes, energy, and commitment are vital resources that can make or break an enterprise" (as cited in Bolman \& Deal, p. 121, 2008). 


\section{Ethical Leadership}

Ethical leadership has become more prevalent as an authentic type of leadership placing ethical considerations at the forefront of decision making. By the nature of education and the impact education has throughout a person's life, school districts must think about whether their decisions, as well as the outcomes, are ethical. This analysis of ethical leadership will take place through the lens of five principles of ethical leadership: respect, service, justice, honesty, and community (Northouse, 2013). Respect is used as a leadership tool within educational institutions in the way that people are treated. This is evidenced in my building through an ongoing model of "Be Nice" instituted by our new principal. This is a consistent reminder that desired student behavior should be modeled by the adults.

Ethical leaders use service to others as a leadership practice. Some leaders embrace service as a main principle, encompassing an entirely new style called servant leadership, in which leaders put others' well-being as a driving component in decisionmaking (Northouse, 2013). This is often demonstrated through coaching, mentoring, and relationship building. This can also be demonstrated by supporting others and their goals. This is evidenced at Nateville high school by administrators' support of teachers and students through interactions with curricular and extracurricular activities, beyond the required administrative supervision. Additionally, social media is used in a positive manner at Nateville high school by administrators to promote successes both school wide and individually.

Ethical leaders are fair and just. As teacher leaders, it is bad practice to show favoritism toward students in which some are treated differently than others. Good school administration does the same, treating all subordinates fairly and with ample generosity 
of good-will. Ethical leaders are honest (Northouse, 2013) and humble. Honesty and humility promote trustworthiness. When teachers and administrators trust one another, excellence is achieved. This is evidenced in the researcher's building in email communications from administrators discussing leadership strengths and weaknesses, as well as surveys desiring feedback for continual improvement. Finally, ethical leaders build community through relationships to facilitate the achievement of common goals.

Bolman and Deal (2008) describe ethical guidelines in decision-making through mutuality, generality, openness, and caring. Mutuality describes the situations in which all members have the same information and are not being misled. Generality means that the rules are applicable among similar organizations and situations. The rules are generally accepted in the industry and are widely known. In this case study of Nateville School District, the standard learning objectives are initiated by the state, and allows for the different levels of testing that all school districts must use as accreditation guidelines. Within Nateville public school district, the "rules", at least at the state level, are governed by a state education body for which other school districts are governed. The state education body is governed by the federal department of education. This provides the structure to allow for generalizability among state and national school districts.

Openness within a school district is assisted by the fact that school board meetings are open to the public by law, barring a few specific exclusions for privacy or personnel matters. By attending board meetings, all stakeholders can hear the same information that the school board is hearing or giving which allows for a level of transparency. Caring shows that a person has the feelings and best interest of others in mind when making decisions, rather than forsaking others to benefit oneself. Examples of 
a caring attitude are exhibited by both the principal and assistant principal at Nateville High School in the way that students and staff are treated.

Ethical leadership can be shown through the administration, but also the teachers and their students. Ethical leadership is viewed through how people are treated, or as Bolman and Deal (2008) describe as the human resource frame. How institutions treat people directly affect the productivity and efficiency of the organization, which in turn, affects the achievement of organizational goals. The human resource frame considers people's needs, as described in Maslow's hierarchy of needs (Bolman \& Deal, 2008). Additionally, the way people treat others can be influenced by their basic assumptions of others and how people are motivated, called Theory $\mathrm{X}$ and Theory $\mathrm{Y}$ leadership styles (McGregor, 1960/2005). In the researcher's teacher training, pre-service teachers were taught to believe that every student is capable of success and that everyone has value.

\section{Servant Leadership}

Ethical leadership focuses on attitudes and decision-making; servant leadership focuses on leader behavior. Servant leaders focus on the greater good of the organization (Northouse, 2013). This is exhibited in my building by the way decisions are made for the best interest of the students. Servant leaders exhibit strong interpersonal skills who nurture and encourage growth and betterment of others. Servant leaders are concerned with the marginalized populations, and try to improve social injustices and inequalities. Leaders in schools try to provide equal access and opportunities for all students, not because it is lawful, but because it is the right thing to do. Servant leadership occurs more often in specific types of organizations. In educational organizations and other nonprofits "...the norm of caring is more prevalent, while for Wall Street corporations it is more common to have competition as an operative norm (Northouse, 2013, p, 226). 
Teacher leaders in Nateville high school use differentiated instruction as a pedagogical method to provide equal opportunities for success. Socially, servant leaders create an environment of acceptance and love. The researcher witnesses this every day at lunch when a former graduate with disabilities is working in the school cafeteria getting smiles and hellos from the entire school. Many of the leaders in Nateville School District exhibit servant leadership, both in administration and each of the classrooms.

\section{Situational Leadership}

A very common type of leadership in schools is situational leadership. This theory describes a leader's behavior depending on the varied situations and people that are present (Northouse, 2013). The premise of situational leadership is that styles change as the needs or development of the people or teams change, like a chameleon changes their colors depending on their environment. A leader needs to be flexible and versatile to master situational leadership skills. Furthermore, leaders need to possess a certain intuitiveness to determine the needs of the group. Hersey and Blanchard pioneered the study on situational leadership for which leaders adapt their style to fit followers' ability and confidence (Northouse, 2013) by adjusting their task and relationship strategies. This has been evident at Nateville high school in the emphasis on relationship building, as both administrators are newer to the building.

\section{Leadership Evaluation Process}

Part of the administrative leadership responsibilities within Nateville high school, as well as all other school buildings, includes the evaluation of teacher effectiveness. These evaluations work to measure and guide teacher effectiveness to create the best possible chance for student achievement. The state-provided educator evaluation system that guides teacher evaluations contains nine standards. Two of these standards directly 
contain student engagement components. Standard two is student learning growth and development, and standard five is positive classroom environment (Missouri Department of Elementary and Secondary Education, n.d.). Understanding teachers' perceptions of student engagement provides the canvas for teachers to apply pedagogical paint, so students can create a masterpiece of academic achievement.

\section{Implications for Research in the Practitioner Setting}

Through this research on teacher perceptions of student engagement, a broader sense of student engagement in a high school classroom can guide professional development and scholarship. This could highlight various teacher perspectives to provide more awareness on a more generalizable level on student engagement. This research could highlight any discrepancies between current practice and scholarship with the goal of raising student achievement through increases in student engagement.

\section{Summary}

The history and organizational analysis of Nateville school district and high school provide context in which to understand this study, its results, and ultimate impact of the research. The structure of an organization "...both enhances and constrains what an organization can accomplish” (Bolman \& Deal, 2008, p. 50). Teacher perceptions of student engagement can be influenced by student demographics and the constraints of teachers. A timeline of the physical facilities and updates, as well as the creation of new programs provides information about where the district has been and where it is going. 


\section{SECTION THREE: SCHOLARLY REVIEW FOR THE STUDY \\ Introduction to the Problem}

A high percentage of students at the high school level are not engaged with the content or academic activities within the classroom setting (Harris, 2011). In fact, the number of disengaged students increases as they progress through school (Corso et al., 2013; Klem \& Connell, 2004; Eccles \& Wigfield, 2002). Newmann (1992) used data from research conducted by the National Center on Effective Secondary Schools (The Center) which highlighted a $7^{\text {th }}$ grade student whose academic achievement had been consistently low. The experience of this student's academic achievement with good grades in elementary, then increasingly lower grades as he progresses through school, seems to enforce the research that student engagement/motivation decreases as students progress through school (Corso et al., 2013; Klem \& Connell, 2004; Eccles \& Wigfield, 2002).

\section{Purpose of the Study}

Many links have been established between engagement and academic achievement (Lee \& Shute, 2009; Antaramian et al., 2010; Kuh, 2001). By studying teachers' perceptions of student engagement, best practice methods can be utilized for continued improvement in academic achievement. This could include what has worked and what has not worked in hopes of creating a rich and thick description of a multitude of varied and effective teaching strategies. The purpose of this study is to collect, combine, and analyze secondary teachers' thoughts and stories on daily student engagement within their classroom. 


\section{Theoretical Framework}

By examining the problem and purpose through a theoretical framework, researchers will be able to pinpoint what to observe and how to analyze the data. "The theoretical framework is the body of literature, the disciplinary orientation that you draw upon to situate your study" (Merriam, 2009, p. 68). This framework to examine secondary teachers' perspectives of student engagement in this study is adult learning theory. Teachers have a unique way of looking at and thinking about things. One of the aspects of adult learning is taking into consideration previous experiences (Merriam \& Bierema, 2014) in the learning process. Not only can teachers use their professional experiences in the work place or in teacher preparation programs, but also their personal experiences working with youth in the community or family. This becomes what is known as "practical knowledge" (Elbaz, 1981) which serves as a "vast repertoire of procedures, beliefs, dispositions, and understandings that enable them to teach in a wide variety of settings" (Erickson et al. 2005, p. 795).

Based on new research within adult learning theory, there is a new stage of development called emerging adulthood, according to Arnett (Merriam \& Bierema, 2014). This "emerging adulthood" stage describes those between 18 and 25 years of age

who are neither adolescents nor young adults. This researcher will use the theoretical framework of adult learning theory to gather meaning and understanding of possible differences in perspectives of student engagement.

\section{Student Engagement}

The first pillar of this research is student engagement. Kidwell states that "student engagement is active learning and includes service learning, problem-based inquiry, organized debate, facilitated classroom discussion, and expository or persuasive writing" 
(2010, p. 30). Carini et al. (2006) examined the extent that student engagement is associated with academic performance.

\section{Engagement and Achievement}

The problem of low student engagement can lead to numerous negative outcomes (Harris, 2011). The National Research Council and Institute of Medicine (2004) reports "dropping out of school is for many students the last step in a long process through which students become disengaged from school" (p. 24). Willms states that low student engagement leads to $25 \%$ of students' sense of low belonging, and $20 \%$ regularly absent from school (Willms, 2009). Subgroups of at-risk students, defined by Donnelly (1987) as minority, low-income, and with disabilities, tend to demonstrate lower levels of engagement (Harris, 2011), which may be one factor leading to the widely documented achievement gap. Student engagement is one factor that contributes to higher student achievement, particularly within subgroups (Lee \& Shute, 2009; Antaramian et al., 2010; Kuh, 2001). Antaramian et al. stated, "students who are more engaged in school tend to have higher grades and better performance on standardized tests" (2010, p. 464).

Corso et al. (2013) state that, "the degree to which students think, feel, and act engaged in school plays a vital role in their chances for academic and life success, yet levels of student engagement remain low." Their research examines how engagement works within a framework of interactions between students, teachers, and the class content. Corso et al. (2013) propose a model that can be understood in terms of relationship, teacher's knowledge of content and pedagogy, and relevance to student. A limitation to this model is that it has not been tested nor does it take into consideration factors outside of the classroom in relation to student engagement, such as extracurricular activities. Forneris, Camiré, and Williamson examined the self-reported effects of 
involvement in extracurriculars and student engagement concluding, "Youth involved in both sport and non-sport extra curricular activities scored higher on perceived school engagement than youth who are not involved in any extracurricular activities (2015, p. $53)$.

\section{Engagement and Age Levels}

Not only has student engagement been shown to help raise achievement in K-12 schools, but also at the undergraduate level as measured by identified behaviors on the National Survey of Student Engagement (NSSE) as cited by Kuh (2001). There are other survey instruments used to measure student engagement in addition to the NSSE, including the Student Engagement Instrument (SEI), and the Fredericks' School Engagement Scale, (Appleton, Christenson, Kim, \& Reschly, 2006).

Kuh, Kinzie, Buckley, Bridges, and Hayek examined how a postsecondary institution allocates its resources, organizes curriculum, and supports services to encourage students to participate in activities that lead to desired outcomes for students, such as persistence in schooling, satisfaction, learning, and graduation (as cited in Auken, 2012). Many others have done studies at the college level (Jackling \& Natoli, 2011; Zhang, Hu, \& McNamara, 2015; Hamady, Ludy, Anderson, \& El-Khechen, 2014; Brint, Cantwell, \& Hanneman, 2008; Tinto, 1987; Auken, 2012). Kuh's work focuses on the undergraduate level, while Gentilucci's analysis of data is from a study of $6^{\text {th }}$ grade students, with Zyngier focusing on elementary levels.

Carini et al. (2006) showed a positive, yet weak, relationship between student engagement and academic performance. Even though the relationship was weak, it showed that lowest ability students benefitted the most. Furthermore, some institutions did convert student engagement into higher performance on critical thinking tests, such as 
RAND (Carini et al., 2006). More research needs to be conducted to study how institutions were able to effectively raise performance based on student engagement more than others.

To understand student engagement and motivation for secondary students, it is imperative to understand how biologically they learn and how the brain of an adolescent works. According to Caskey and Ruben, the largest part of the brain that is responsible for complex thinking, memory, and impulses is the "slowest to develop during adolescence" (2003, p. 37). Because of this biological growth timeline, adolescents automatically revert to the part of the brain which regulates emotions, and other "gut" reactions. Finally, the process involved in developing the part of the brain that controls more complex thinking is not complete until about age 20. This process occurs earlier in girls than it does in boys. Caskey and Ruben (2003) assert that this explains to some degree, why the actions of teenage boys are not as well thought out, as of girls' actions.

Antaramian et al. (2010) used a quantitative study to examine how mental health affected middle school students in terms of student engagement, academic achievement, and environmental support for learning. There was a correlation between mental health and academic and behavior outcomes. Social well-being (SWB) was defined as "the way in which and the reasons why individuals experience their lives positively" (Antaramian et al., p. 462). There was just as much risk for those groups that had a low SWB score and a low psychopathology (mental disorder) score as the 'troubled' group that had a low SWB score and a high psychopathology score. The low SWB and low psychopathology score group would be considered mentally healthy based on traditional means of measurement, but faced just as much risk of negative performance and behavioral outcomes as the group that showed high mental illness scores. The best performance was 
carried out by those with high (or positive) SWB and low (or absence of) psychopathological symptoms. This research emphasizes the importance of the perceptions of well-being and that true health is not just the "absence of illness" (Antaramian et al., p. 462). Students with positive mental health were more engaged behaviorally, cognitively, and emotionally. The Antaramian et al. (2010) study used multiple engagement tools such as the Behavioral Engagement Subscale from the Fredericks' School Engagement Scale, as well as the School Satisfaction Subscale.

Finally, the cognitive Engagement Scale from the Future Aspirations and Goals Subscale of the Student Engagement Instrument (Appleton et al., 2006) was used. Other studies have used the Check \& Connect intervention program to measure engagement (Intervention, 2014).

One limitation to this study is the location being in one single middle school in one South Eastern state. This inhibits the generalizability of the study. It was also selfreport surveys, which draws into question the reliability and honesty of the answers. Furthermore, it was also a cross-sectional sample which does not show a change in mental health status over time.

\section{Teacher Perceptions}

Harris (2011) did a qualitative and phenomenological study focusing on secondary teacher perceptions of student engagement in Australia. Harris states that student engagement usually falls within four categories: behavioral, academic, psychological, and cognitive. Behavioral engagement describes attendance, participation in the classroom and outside the classroom in extracurricular activities, compliance (or non-compliance) with school rules. Academic engagement describes students' grades, time spent on homework, credits earned, amount of accurate homework completed. 
Psychological engagement includes factors like interest, support, attitudes toward school, sense of belonging and connection to school. Lastly, cognitive engagement describes the goal-setting, motivation, and commitment to learning (Harris, 2011). The Check \& Connect system has similar definitions for the four types of engagement, except their term for psychological engagement is affective engagement. Willms (2009) describes three dimensions areas of engagement: social, academic, and intellectual. Social engagement is a sense of belonging and participation in school life; academic engagement is attendance at school; and intellectual engagement is being intellectually challenged and motivated or interested in school. Appleton et al. (2006) describes engagement similarly to Check \& Connect, except the nomenclature of psychological engagement and Check \& Connects' affective engagement.

\section{Student Perceptions}

Many studies examine student perceptions (Appleton et al., 2006; Economos, 2014; Ozdemir \& Kalayci, 2013; Newmann, 1992), but fewer studies research how teachers think and feel about student engagement. Auken (2012) did a case study of his own with undergraduate students and their perceived engagement in his sociology classes. Gentilucci (2004) studied student perspectives on learning, which is very closely linked to student engagement. This research expands on the subjectivist approach which investigates students' thoughts and feelings on how they learn and behave. This study was conducted with elementary students based on data from 1978-1979 school year, validated as still current by a focus group held 20 years later to ensure topics and thoughts were still relevant. This study only used two classrooms, but an extensive number of interviews. 
Results showed that there are things that elementary students think interfere with their learning. These are unchallenging curriculum, teacher misbehavior, overuse of cooperative learning, and inadequate instruction. The students in this study thought the major contributor of poor learning was inside the classroom, not outside. Gentilucci (2004) suggests based on the results of this study, that student learning is not as multifaceted and ambiguous as previously thought, which makes further research prudent for real and pragmatic solutions.

\section{Knowing-Doing Gap}

The second pillar in the discussion of teachers' perceptions of student engagement, is the knowing-doing gap. According to Pfeffer and Sutton's The Knowingdoing Gap: How Smart Companies Turn Knowledge Into Action (2000), this gap describes the disconnect between what people know and what they actually do to bring about change or improvement. This problem is broadly discussed within the realm of organizational theory (Pfeffer \& Sutton, 2000; Zheltoukhova, 2014; Sparks, 2009).

\section{Less Talk More Action}

According to Pfeffer and Sutton (2000), talking is often used as a substitute for action. For example, presentations, prepartion of documents, mission statements, and planning, often act as a surrogate for implementation. This can occur when there is no accountability for a follow-up on decisions to ensure actions are taking place, or when there is a sense of congeniality and dissent is quashed due to the desire for peace. Finally, this could also occur when short-term goals are being met, and there is a lack of urgency for long-term goals.

Although talking is an important component of the communication cycle, Pfeffer and Sutton (2000) draw attention to the imbalance placed on the importance of talk 
versus action. The first impression is often determined by how smart someone sounds from the way they talk. For example, "appearing smart is mostly accomplished by sounding smart; being confident, articulate, eloquent, and filled with interesting information and ideas; and having a good vocabulary" (Pfeffer \& Sutton, 2000, p. 43). Talking seems to make people sound smarter when they are negative or criticizing others. Pfeffer and Sutton claim, "people scored points by criticizing others' ideas in meetings" (2000, p. 45). This is also corroborated in an experiment titled, "Brilliant but Cruel" by Professor Teresa Amabile of the Harvard Business School, in which "Negative reviewers were perceived as more intelligent, competent, and expert than positive reviewers, even when the content of the positve review was independently judged as being higher quality and greater forcefulness." (Amabile, 1981).

People who talk more are perceived as "influential, high status, and as leaders" (Pfeffer \& Sutton, 2000, p. 46) which is reinforced by business schools and management consulting firms because of the use of talk, rather than action, in the methods of learning. Another common perception of smartness is using, "complex language, complex ideas, complex sentence structure, and complex analysis in addressing organizational issues" (Pfeffer \& Sutton, 2000, p. 51). Inaction due to overly complex language is exacerbated when managers do not know the jargon they are communicating to employees.

\section{Doing Things The Same Way}

Another problem contributing to the knowing-doing gap is memory substituting for thinking (Pfeffer \& Sutton, 2000). This can be summed up as continuing to do what has always been done without reflecting on the value or effectiveness. The tendency to establish a precendent is even strong only after doing something for one time according to behavioral scientists, as it "often becomes an automatic, or mindless, guide for future 
action, even when the action undermines a person's performance" (Pfeffer \& Sutton, 2000, p. 69). Admittedly, Pfeffer and Sutton claim, "at its best, doing things the same way provides continuity and helps define and establish an organization's culture and values" (2000, p. 75). Ways to counteract using memory as a substitute for thinking include designing a unique culture or having the flexibility and authority to break away from the precedents of parent company (Pfeffer \& Sutton, 2000). Additionally, companies can educate people on problems associated with doing things the same as before, as well as making it harder to do things the old way, while creating and providing alternative ways of doing things (Pfeffer \& Sutton, 2000).

\section{Measure the Right Things}

Yet another factor contributing to the knowing doing gap is using the wrong measurement criteria to guide decisions. Pfeffer and Sutton (2000) found that a basic tenet of companies who used measurements that actually helped bridge the gap between knowledge and action, measured things that were "core to their culture and values" ( $\mathrm{p}$. 160). The measures aligned with company strategies, as well as what the company viewed as important to the successful sustainability of the operations.

\section{Detrimental Competition}

Another problem that contributes to the knowing-doing gap is the use of competition that ultimately undermines communication, collaboration, and learning within an organization. Pfeffer and Sutton (2000) state, "there is little internal learning because competition for status and management attention interferes with the transfer of better ways of doing things" (p. 186). Alfie Kohn offers this idea, "children succeed in spite of competition, not because of it” (Kohn, 1987). 
Given all these factors that contribute to the knowing-doing gap, Pfeffer and Sutton (2000, p. 246) recommend ways to counteract these problems including:

- Understand the philosophy or the why before the how.

- Knowing comes from doing and teaching others how.

- Action counts more than talk.

- Reward trying; avoid punishing mistakes or failures.

- Avoid using fear as management style.

- Collaborate and cooperate; do not compete.

- Measure the things that promote culture and values.

- Leadership creates culture that values knowledge buidling, sharing, and acting.

\section{Knowing-Doing Gap in Education}

As the knowing-doing gap is related to education, and to this study in particular, the specific knowledge that teachers' have of student engagement can be partly attributed to state licensing requirements for teachers. For example, the Missouri Department of Education teacher evaluation process includes student engagement indicators for new and veteran teachers in standard 1.2; 2.3; 2.4; and 2.5 (Missouri Department of Elementary and Secondary Education, n.d.). Additionally, prior training in a teacher preparation program, job experience, and ongoing professional development will inform teachers' knowledge. Bussis, Chittenden, and Amarel (Elbaz, 1981) examined what they called "teachers' understandings" which informs the notion "the teacher as holding and actively using knowledge to shape the work situation and guide teaching practice" (p. 46). Elbaz further explains the nature of teachers' knowledge as: 
...knowledge of subject matter; of classroom organization and instructional techniques; of the structuring of learning experiences and curriculum content; of students' needs, abilities, and interests; of the social framework of the school and its surrounding community; and of their own strengths and shortcomings as teachers. (1981, p. 47)

Job experience will also build teachers' knowledge, as trial and error is an oftenused strategy. Pfeffer and Sutton call this tacit knowledge (2000), and indicate the action of doing as more beneficial than talking about doing, as immediate problems can be addressed in the context of the job. This also helps to shrink the knowing-doing gap in which nothing seems to get done.

\section{Pedagogy}

The third pillar for this research study is pedagogy. The origin of the word, pedagogy, or "child-tender", comes from the Greeks and described a person that cared for and taught children (Smith, 2012). Plato viewed pedagogues as "leaders and custodians of children" (Longenecker, 1982, p. 53). Smith (2012) distinguishes between subject specialists and pedagogues, in which pedagogues encompass a more holistic approach. According to the work of Pestalozzi, education is "the natural, progressive, harmonious development of all the powers and faculties of the human being" (as cited in Monroe, 1912, p. 315). This holistic approach has contributed to the development of the concept of social pedagogy that moves beyond direct curriculum. For example, teachers can provide environments that promote learning such as, "meaningful active engagement, sense of belonging, high level of support for achievement, sense of empowerment, more 'on-ramps', and resiliency skills”' (Tileston, 2011, p. 24). 


\section{Cooperative Learning}

The trend of educational theory is moving away from didactic teaching theory that became popular during the industrial age as the most efficient way to teach the masses of students, and moving toward more constructivism theory where learning is student centered and more experiential. With the overabundance of standardized tests that students take, particularly with the most recent adoption of Common Core standards, pedagogy is changing to meet the needs of this high-stakes environment, for better or worse.

Garcia and Pacheco state that cooperative learning is an, "interaction with different intellectual capabilities of students to improve the group learning and, by consequence, individual learning" (2010, p. 565). Additionally, Vygotsky states, "in a cooperative scenario, the students interchange their ideas for coordinating them to achieve shared objectives. When the problems arise, the combination of activities with communication will conduce to learn" (as cited in Garcia \& Pacheco, 2010, p. 565). Garcia and Pacheco propose that the process of constructing the knowledge with others not only increases the shared knowledge, but also the individual knowledge. Another tenet of cooperative learning is the movement toward more student-centered learning. Gurbuz, Simsek, and Berber (as cited in Genç, 2016) discuss how the role of the teacher has transformed into a guide of student learning, rather than an imparter of information. This, in turn, creates an opportunity for the student to take a more active role in his or her individual learning process.

\section{Prior Knowledge}

Not only do advanced organizers help build prior knowledge before learning occurs, but also throughout the lesson as they help organize concepts to clarify learning. 
This can be done during the note-taking stages, as well as providing focus during oral lessons. Often, similarities, differences, and patterns can be pinpointed visually through advanced organizers which lead to higher order thinking skills on Bloom's Taxonomy. Without prior knowledge, other strategies like discussion or imagery can be used to create a connection that leads to higher achievement and retention in the learning. A meta-analysis through MCREL, showed a 27\% average raise in achievement by using what Marzano calls "direct schema activation" (as cited in Tileston, 2011) by building connections through prior knowledge.

\section{Learning Styles}

Sousa states in his book, How the Brain Learns, only twenty percent of students are auditory learners; the other eighty percent learn either visually or kinesthetically (as cited in Tileston, 2011). Because of this reason, Tileston (2011) recommends that lecture as a teaching method should be limited to 15 minutes or less. This recommendation is also guided by the following claim by Prensky (as cited in Tileston, 2011):

by the time students are 21 years of age, they will have played more than 10,000 hours of video games, sent and received 250,000 e-mails and text/instant messages, spent 10,000 hours talking on phone, watched more than 20,000 hours of television, and been exposed to 500,000 commercials. (p. 33)

After 15 minutes of lecture, activities, discussion, or guided practice should follow to practice new learning (Tileston, 2011). Sousa recommends that the first 20 minutes of class is the "prime time" of teaching and is the time that students learn best (as cited in Tileston, 2011). Elementary students have a shorter attention span, and the time should be adjusted accordingly. Several recommendations by Sousa (2011) to gain the interest of 
students and take advantage of how the brain learns, include using novelty. These include humor, movement, multi-sensory instruction, quiz games, and music.

Table 1

Best Teaching Practices for Auditory, Visual, and Kinesthetic Learners Auditory Learners $\quad$ Visual Learners $\quad$ Kinesthetic Learners

\begin{tabular}{|l|l|l|}
\hline Direct instruction & $\begin{array}{l}\text { Non-linguistic, graphic, or } \\
\text { visual organizers (word } \\
\text { webs, mind maps) }\end{array}$ & $\begin{array}{l}\text { Learn better on feet } \\
\text { (movement) }\end{array}$ \\
\hline Peer tutoring & Point out patterns in learning & $\begin{array}{l}\text { Use all senses to enhance } \\
\text { learning }\end{array}$ \\
\hline Music & Puzzles, pictures, books & $\begin{array}{l}\text { Learning opportunities } \\
\text { outside of classroom (field } \\
\text { trips) }\end{array}$ \\
\hline $\begin{array}{l}\text { Group discussions, } \\
\text { brainstorming, Socratic } \\
\text { seminars }\end{array}$ & $\begin{array}{l}\text { Written instructions and } \\
\text { explanations, written } \\
\text { recordings of discussions }\end{array}$ & $\begin{array}{l}\text { Assembly and disassembly, } \\
\text { discovery learning }\end{array}$ \\
\hline Oral activities & Models, examples & $\begin{array}{l}\text { Hands-on activities, } \\
\text { simulations, manipulatives }\end{array}$ \\
\hline Verbalize the learning & $\begin{array}{l}\text { Essays, reports, worksheets, } \\
\text { where writing is involved. }\end{array}$ & $\begin{array}{l}\text { Physical rewards, such as } \\
\text { pat on the back }\end{array}$ \\
\hline (self-talk) & \multicolumn{2}{|l}{} \\
\hline
\end{tabular}

Differentiation is a strategy used in all group sizes. The premise of this strategy is to help students understand as well as the teacher how the student learns best, and use strategies that focus on the individual student's needs (Tileston, 2011). These individual learning preferences may be created based on the physical changes in the brain through each new experience (Doidge, 2007). His research showed, "the brain changed its very structure with each different activity it performed, perfecting its circuits so it was better suited to the task at hand" (p. xviii). 


\section{Summary}

Within this scholarly review, adult learning was highlighted as the theoretical framework for which to view the research. Because this study focuses on teachers' perceptions, the ways in which adults learn differently than youth must be taken into consideration. For example, "adults are motivated to learn by significant work and life changes and believing that what they will learn will help them cope with those changes" (Gill, 2010, p. 61). The link between student engagement, the knowing-doing gap, and pedagogical trends are examined. The history of federal mandates was outlined as it relates to the current trend of pedagogy in education. This scholarly review will be one component for the triangulation of data to ensure validity of the study of teacher perceptions of student engagement. 


\section{SECTION FOUR: CONTRIBUTION TO PRACTICE \\ Plan for Dissemination of Practitioner Contribution}

Who: Nateville High School

When: Fall, 2017

How: Present on Professional Development day to the high school Administration and faculty

\section{Type of Document}

Document will be a slide show presentation.

\section{Rationale for this Contribution Type}

The information and results of this case study will be immediately applicable to Nateville High School and School District due to this being the location of the study. The administrators will have a baseline of teachers' perceptions of student engagement to guide future training and professional development.

\section{Outline of Proposed Contents}

Background Information on Nateville School District

Research on student engagement, the knowing doing gap, and pedagogy

Findings - Qualitative results based on interviews

Implications and Impact of research results 


\title{
Teacher Perceptions of Student Engagement
}

Definitions, Factors, Obstacles, Improvement Strategies

\section{A Qualitative Case Study \\ Nateville High School (pseudonym)}

\author{
Dasha D. Davis \\ University of Missouri \\ ddavis@savannahr3.com
}




\section{Statement of the Problem}

It is estimated that $40 \%$ of students at the high school level are not engaged with the content or academic activities within the classroom setting (Crotty, 2013). In fact, the number of disengaged students increases as they progress through school (Corso, Bundick, Quaglia, \& Haywood, 2013; Klem \& Connell, 2004; Eccles \& Wigfield, 2002).

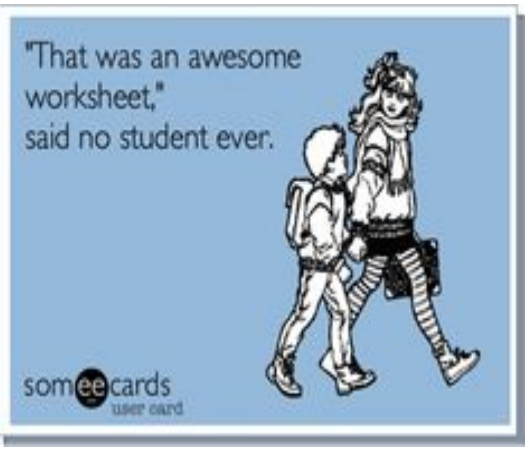

http://www.curriculumresources.net/blogseries/teaching-with-our-eyes-open-lessons-instudent-engagement-and-knowledge-retention/

\section{Consequences of Dropping Out of School}

- According to Corso et al. (2013), "Dropping out is highly likely to have serious negative long-term consequences, such as difficulty finding employment and reduced quality of life" (p. 51).

- Even when employed those without a high school diploma will make $\$ 15,000$ less than the median wage of someone with a high school diploma (Torpey \& Watson, 2014), often plunging them into poverty (Rumberger, 2013).

- Thornberry, Moore, and Christenson (1985) concluded that drop-outs have more incidences of criminal activity leading to incarceration than peers who did not drop out. 
The National Research Council and Institute of Medicine (2004) reports "dropping out of school is for many students the last step in a long process through which students become disengaged from school" ( $p$. 24).

- Nateville dropout rate for $2016,1.3 \%$

(Missouri Department of Elementary and Secondary Education, n.d.)

- Missouri dropout rate for 2016, 2.2\%

(Missouri Department of Elementary and Secondary Education, n.d.)

- U. S. high school drop out rate for $2015,5.9 \%$

(U.S. Department of Education Fast facts, 2017).

\section{Connection between Engagement and achievement}

- Research shows that student engagement is one factor that contributes to higher student achievement, particularly within subgroups (Lee \& Shute, 2009;

Antaramian, Huebner, Hills, \& Valois, 2010; Kuh, 2001). Lee and Shute (2009) stated: "To achieve academic success, students should be engaged with learning, be able to apply basic learning strategies to grasp the learning material, and be surrounded by positive social-environmental influences that are generated by or obtained from school, peers, and their parents" (p. 6).

- Antaramian et al. stated, "students who are more engaged in school tend to have higher grades and better performance on standardized tests" (2010, p. 464). 


\section{Purpose of the Study}

- Use data from the study to implement strategies for increasing student engagement in the classroom, therefore, providing students with more educational opportunities to succeed and achieve to the best of their ability, as well as reducing the number of potential drop outs.

- Aid in the reflections of teachers when preparing, teaching, and adjusting teaching strategies and theory on student engagement with the desire of meeting the needs of the $21^{\text {st }}$ century learner.

- Student engagement increases achievement. Achievement improves graduation rates, achievement gaps, overall achievement, college enrollment and persistence.

\section{Adult Learning Theory}

- Merriam and Bierema (2014) - adult learners have numerous roles and responsibilities in addition to being a student learner.

- Adults bring more life experiences into the learning sphere which provides a more robust basis of prior knowledge and context to learning. As a result, the motivations for adult learning vary as the person desires to improve their life, perhaps for a job, personal, or social purposes (Merriam \& Bierema, 2014). 


\section{Adult Learning Theory and Teacher Professional Development}

Educators want and need more meaningful, purposeful, and quality professional development that not only helps them with their teaching, but also "affirm[s] their practice" (Eldridge, 1998, p. 500).

Fullan states that 'teachers' jobs are more complex than ever before. They must respond to the needs of a diverse and changing population, a rapidly changing technology in the workplace, and demands for excellence from all segments of society" (Fullan, 1993, p.5).

\section{Adult Learning Theory and Student Engagement}

Adult learning theory provides framework for how teachers' professional, personal, and educational experiences shape their views on student engagement in the educational setting.

"I think everybody brings other perspectives in. You are a sum of all you've met," Participant 8 stated when asked if she brought experiences in from other jobs before entering into education.

How teachers learn (adult learning theory) will influence how they understand, evaluate, and promote student engagement. 


\section{$\underline{\text { Research Question }}$}

- What are teachers' perceptions of student engagement in one Midwest rural high school?

\section{Design of the Study}

- This study will be conducted within a bounded system of one high school, in other words, "a single entity, a unit around which there are boundaries" (Merriam, 2009, p. 40).

- Qualitative - researcher is the primary data gatherer and uses an inductive process to "establish comprehensive themes" (Creswell, 2014, p. 186; Merriam, 2009).

- The researcher will maintain a non-participant role in the observation (Creswell, 2014). 


\section{Design of the Study}

- The researcher is an employee of the district (in the building of case study) and a parent of a student at Nateville High School.

- Special attention will be given to the fact that the research is considered "backyard" research, coined by Glesne \& Peshkin in 1992 (as cited in Creswell, 2014, p. 188) in which the setting is the immediate work environment of the researcher.

\section{Study Specifics}

- Qualitative (Merriam, 2009)

- Bounded Case Study

- Interviews - Interview participants included two high school administrators, two members of the RPDC, and ten high school teachers

- Walk through classroom observations

- Literature review 


\section{Study Specifics - Limitations}

- Small size of the study, limited time allocated, as well as the time of the school year (last month of school).

- Limited generalizability of a qualitative case study (Merriam, 2009).

- Researcher is a faculty member of the school in the case study, so maintaining positive relationships, as well as employment was essential.

\section{$\underline{\text { Study Specifics - Delimitations }}$}

- The researcher did not interview anyone within the researcher's own department due to potential bias.

- No other schools within the district were chosen as population samples, due to time constraints and easier coordination of scheduling with the researcher's schedule.

- Only three males were asked to participate in the interviews due to the limited number of male teachers, and the desire of the researcher to interview many different departments - several male teachers were in the same department. 


\section{Study Specifics - Assumptions}

- Participants were honest and forthcoming with their input with the intention of furthering scholarship, rather than ulterior motives that would skew the data results.

- All participants were willing and felt no obligation to be involved in the study.

\section{History of the Organization}

- 1878 -Nateville Public School's first commencement (Alumni Association, 2017) with five women graduates.

- 1932 - a fire that burned down the school, which at the time held grades one through twelve. A new school was built.

- 1950s - District reorganized,Hawkins School Reorganization Act of 1948, consolidating rural schools to form more efficient school districts (Alumni Association, 2017). 


\section{History of the Organization}

- 1957 - new elementary school built (MC), so the old high school became a junior and senior high school.

- 1963 - new high school built, leaving only the junior high students in the 1932 building. This building was torn down in 2010, when an additional middle school was built to house $6^{\text {th }}, 7^{\text {th }}$, and $8^{\text {th }}$ grades (Alumni Association, 2017).

\section{$\underline{\text { History - Facilities }}$}

- This facility was built in 1963 (Long-Range Facilities Plan, 2006). More classrooms were added in 1968, with more additions being built in 1972, 1988, and 2000 (Alumni Association, 2017). In 2000, the community voted to pass a lease-purchase issue on the ballot that provided for the construction of a new science wing at the high school, as well as a new concession stand and restrooms at the high school athletic field. 


\section{$\underline{\text { History - Facilities }}$}

- In 2006, the Nateville School District created a plan for long-range facilities as a "planning tool that informs the organization, provides a framework for sound decision making, and enables the school district to effectively anticipate, respond to and manage change" (LongRange Facilities Plan, 2006).

- After an assessment of needs by community patrons, administrators, board of education, and school district employees, "new construction, renovation, demolition and general improvement to the physical facilities were recommended" (Long-Range Facilities Plan, 2006).

\section{$\underline{\text { History - Facilities }}$}

- The recommendations were proposed in three phases, starting with a target year of 2007 for completion of the first phase.

- First phase included building a new middle school, new library at the high school, expansion of existing spaces, additional classrooms, relocation of principal and nurse offices closer to main entrance in two of the elementary schools, as well as safer and secure entryways to all buildings.

- Phase two included creation of a performing arts center at the high school for district and community use and relocation of classrooms and parking lots. Library areas would be expanded at two of the elementary schools with the creation of independent technology labs.

- Phase three included improvement of athletic seating and accessibility at the high school athletic field. 


\section{$\underline{\text { History - Facilities }}$}

- Construction would start during phase three for a new elementary school if an assessment was made during phase two that it was needed. Phase two and three would be completed without an additional tax increase planned, given a target date of 2020 for phase three. At the time of this writing, phase one has been completed and planning has started for the completion of phase two.

\section{$\underline{\text { History - Facilities }}$}

- In 2009, during the long-range facilities plan implementation, Nateville began a pre-school program for children with special needs. In 2016, Nateville School District received a \$1 million-dollar community development block grant for early childhood education through the Missouri Start Smart initiative and the Department of Economic Development. The district will build a 7,088-square foot early childhood education center that will educate 80 preschool students (Hall, 2016). 


\section{Organizational Analysis}

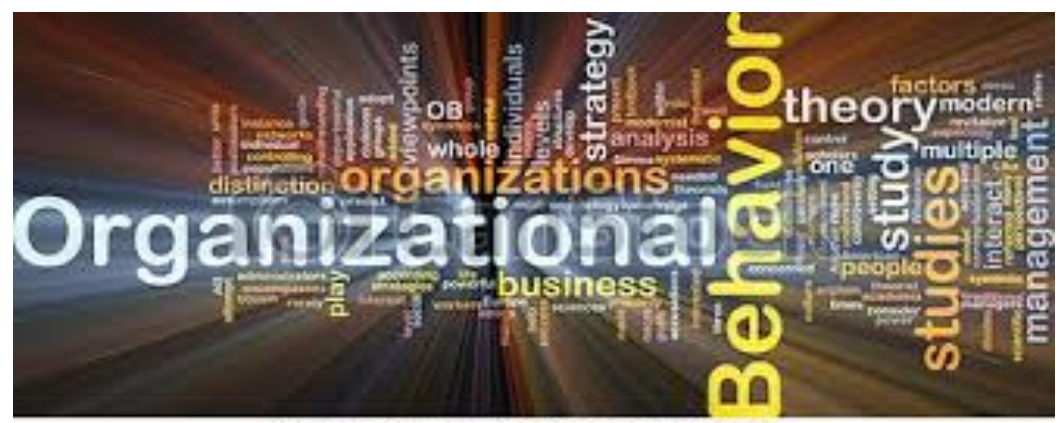

Can Stock Photo - csp6137064

http://www.canstockphoto.com/organizational-behavior-isbone-6137064.html

\section{Nateville School District Mission}

- This planning and decision-making through the organizational structure are facilitated by aligning with the mission of the district, which is to nurture, inspire, challenge, and encourage every student by providing the education necessary to become a productive member of society (Nateville High School, n.d.).

- Strategic priorities set by the school board (strategic apex), create the framework and goals for the district as it moves forward maximizing the engagement and achievement of the $21^{\text {st }}$ century learner. 


\section{$\underline{\text { Nateville District Strategic Goals }}$}

- to seek individual student achievement through a challenging curriculum;

- to retain and attract high quality personnel by developing a health and wellness program, increasing PD and collaboration time, enhancing a teacher mentoring program, enhancing salaries, and developing procedures for collective bargaining;

- to increase and maintain community partnerships by creating a district foundation, enhancing community connections, improving community outreach and communication;

(Nateville School District, 2015).

\section{Strategic Goals, (Con't)}

- to provide a high quality learning environment by enhancing facilities, developing a technology plan to meet current and future needs, enhancing safety for students and staff in all the schools;

- fiscal responsibility and revenue generation by finding alternative resources of funding and examining purchasing procedures (Nateville School District, 2015). 


\section{Organizational Analysis}

- The structure of the organization creates a hierarchy of leadership, not only for creating and implementing policies, but also providing the instructional leadership to teachers which directly affects student engagement in the classroom.

- Nateville School District follows Mintzberg's five basic parts of an organization with a "distinct division of labor" (1979/2005). Mintzberg's model allows for more strategic planning and long-term decision-making from the strategic apex without the distractions of day to day operations that the middle line experiences (Bolman \& Deal, 2008).

\section{High School Organizational Structure}

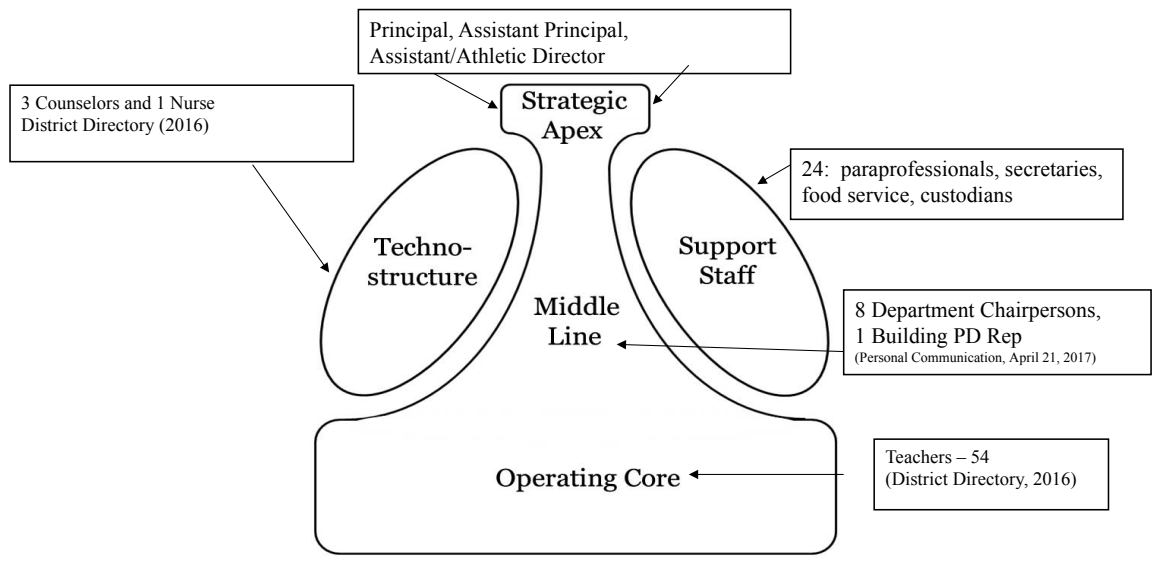

H. Mintzberg, 1979, Reprinted Classics of Organizational Theory, J. Sharfritz, J. Ott, \& Y. Jang (Eds), 2005, p. 220. 


\section{Leadership Analysis}

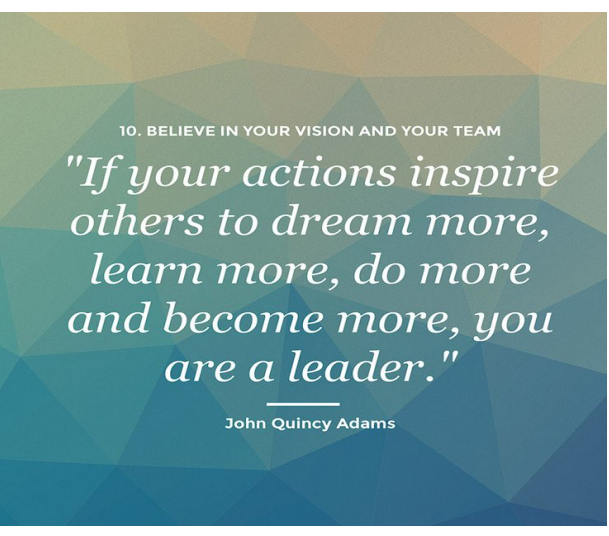

https://s-media-cache-ak0.pinimg.com/736x/f1/13/21/f11321f361474e 747579d 4e9854db43a--quotes-about-leadership-leadership-quotes-educational.jpg

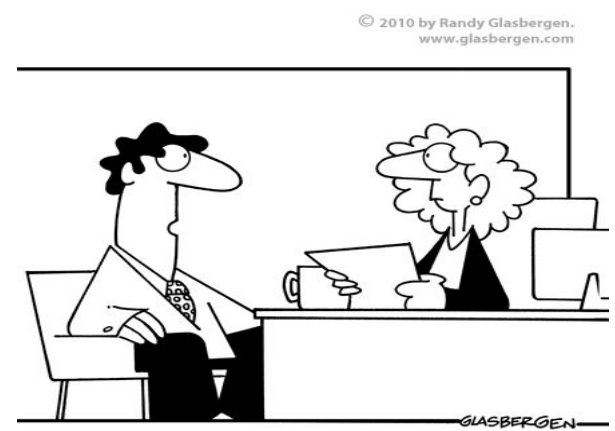

"Leadership experience? I have 13 people following me on Twitter!"

https://s-media-cache-

ak0.pinimg.com/736x/f3/91/99/f391992c0a119b0ef54bf9c5f3833d4 6--business-cartoons-twitter-followers.jpg

\section{Leadership is ethical}

This analysis of ethical leadership will take place through the lens of five principles of ethical leadership: (Northouse, 2013)

- respect

- service

- justice

- honesty

- community 


\section{Leadership is Respect and Service}

- Respect - evidenced through an ongoing model of "Be Nice" instituted by our principal. This is a consistent reminder that desired student behavior should be modeled by the adults.

- Service - evidenced at Nateville high school by administrators' support of teachers and students through interactions with curricular and extracurricular activities, beyond the required administrative supervision.

\section{Leadership is just, honest, and builds community.}

- Good school leaders treat all subordinates fairly and with ample generosity of good-will.

- Administrators discuss leadership strengths and weaknesses, as well as surveys desiring feedback for continual improvement.

- Builds community through relationships to facilitate the achievement of common goals. 


\section{Ethical Leadership}

- Ethical leadership is viewed through how people are treated, or as Bolman and Deal (2008) describe as the human resource frame.

- How institutions treat people directly affect the productivity and efficiency of the organization, which in turn, affects the achievement of organizational goals.

- This study's purpose is to increase academic achievement or excellence, so leadership must be considered.

\section{Servant Leadership}

- focus on the greater good of the organization (Northouse, 2013). This is exhibited in my building by the way decisions are made for the best interest of the students.

- exhibit strong interpersonal skills who nurture and encourage growth and betterment of others.

- are concerned with the marginalized populations, and try to improve social injustices and inequalities.

- create an environment of acceptance and love. The researcher witnesses this every day at lunch when a former graduate with disabilities is working in the school cafeteria getting smiles and hellos from the entire school. 


\section{Situational Leadership}

- leadership styles change as the needs or development of the people or teams change, be flexible and versatile, and possess a certain intuitiveness to determine the needs of the group.

- Hersey and Blanchard pioneered the study for which leaders adapt their style to fit followers' ability and confidence (Northouse, 2013) by adjusting their task and relationship strategies. This has been evident at Nateville high school in the emphasis on relationship building, as both administrators are newer to the building.

\section{$\underline{\text { Leadership and Teacher Evaluation }}$}

- The state-provided educator evaluation system contains two standards that explicitly deal with Student engagement.

- Standard 2 is student learning growth and development, and standard 5 is positive classroom environment (Missouri Department of Elementary and Secondary Education, n.d.).

- Understanding teachers' perceptions of student engagement provides the canvas for teachers to apply pedagogical paint, so students can create a masterpiece of academic achievement. If the painting was a paint by number - the numbers would be the standards, telling you what color to paint. 


\section{$\underline{\text { In other Research... }}$}

- Newmann (1992) used data from research conducted by the National Center on Effective Secondary Schools (The Center) which highlighted a $7^{\text {th }}$ grade student whose academic achievement had been consistently low.

- The experience of this student's academic achievement with good grades in elementary, then increasingly lower grades as he progresses through school, seems to enforce the research that student engagement/motivation decreases as students progress through school (Corso et al., 2013; Klem \& Connell, 2004; Eccles \& Wigfield, 2002).

\section{Student Engagement at Undergraduate Level}

- National Survey of Student Engagement (NSSE) as cited by Kuh (2001).

- Institutional researchers at Indiana University Bloomington, St. Xavier University, University of Montana, and the University of WisconsinGreen Bay, say the NSSE shows "positive relationships between NSSE results and persistence, as well as academic performance represented by college grade point average (GPA)" (Carini, Kuh, \& Klein, 2006, p. 3). 


\section{Low Student Engagement}

- Willms states that low student engagement leads to $25 \%$ of students' sense of low belonging, and $20 \%$ of students regularly absent from school (Willms, 2009).

- Subgroups of at-risk students, defined by Donnelly (1987) as minority, low-income, and with disabilities, tend to demonstrate lower levels of engagement (Harris, 2011), which may be one factor leading to the widely-documented achievement gap.

\section{Check \& Connect System}

- “...comprehensive intervention to engage students who are showing early warning signs of disengagement form school and learning who are at risk of dropping out."

- focuses on improving student engagement.

- improved elementary attendance and tardiness

- increased parent engagement

- Improved attendance and academic performance for chronically truant students, and decreased skipped classes and out of school suspensions (Check \& Connect Student Engagement Intervention, 2016). 


\section{Adult Learning Theory - in other research}

- One of the aspects of adult learning is taking into consideration previous experiences (Merriam \& Bierema, 2014) in the learning process.

- Not only can teachers use their professional experiences in the work place or in teacher preparation programs, but also their personal experiences working with youth in the community or family. This becomes what is known as "practical knowledge" (Elbaz, 1981) which serves as a "vast repertoire of procedures, beliefs, dispositions, and understandings that enable them to teach in a wide variety of settings" (Erickson, Brandes, Mitchell, \& Mitchell, 2005, p. 795).

\section{Adult Learning Theory - in other research}

- new stage of development called emerging adulthood, according to Arnett (Merriam \& Bierema, 2014).

- This stage describes those between 18 and 25 years of age who are neither adolescents nor young adults. 


\section{Student Engagement in Other Research}

- Kidwell states that "student engagement is active learning and includes service learning, problem-based inquiry, organized debate, facilitated classroom discussion, and expository or persuasive writing" (2010, p. 30).

- Carini et al. (2006) showed a positive, yet weak, relationship between student engagement and academic performance. Even though the relationship was weak, it showed that lowest ability students benefitted the most.

\section{Student Engagement in Other Research}

- Corso et al. (2013) state that, "the degree to which students think, feel, and act engaged in school plays a vital role in their chances for academic and life success, yet levels of student engagement remain low."

- Their research examines how engagement works within a framework of interactions between students, teachers, and the class content.

- Corso et al. (2013) propose a model that can be understood in terms of relationship, teacher's knowledge of content and pedagogy, and relevance to student. 


\section{Student Engagement in Other Research}

- Forneris, Camiré, and Williamson examined the self-reported effects of involvement in extracurriculars and student engagement concluding, "Youth involved in both sport and non-sport extra curricular activities scored higher on perceived school engagement than youth who are not involved in any extracurricular activities (2015, p. 53).

\section{Engagement and Resources}

- Kuh, Kinzie, Buckley, Bridges, and Hayek examined how a postsecondary institution allocates its resources, organizes curriculum, and supports services to encourage students to participate in activities that lead to desired outcomes for students, such as persistence in schooling, satisfaction, learning, and graduation (as cited in Auken, 2012). 


\section{Engagement and Biological Factors}

- student engagement and motivation for secondary students understanding how biologically they learn and how the brain of an adolescent works.

- According to Caskey and Ruben, the largest part of the brain that is responsible for complex thinking, memory, and impulses is the "slowest to develop during adolescence" (2003, p. 37).

- Because of this biological growth timeline, adolescents automatically revert to the part of the brain which regulates emotions, and other "gut" reactions.

- the process involved in this development is not complete until about age 20. This process occurs earlier in girls than it does in boys. Caskey and Ruben (2003) assert that this explains to some degree, why the actions of teenage boys are not as well thought out, as of girls' actions.

\section{Engagement and Mental Health}

- Antaramian et al. (2010) used a quantitative study to examine how mental health affected middle school students in terms of student engagement, academic achievement, and environmental support for learning. There was a correlation between mental health and academic and behavior outcomes.

- This research emphasizes the importance of the perceptions of wellbeing and that true health is not just the "absence of illness" (Antaramian et al., p. 462). Students with positive mental health were more engaged behaviorally, cognitively, and emotionally. 


\section{Engagement Categories}

- Behavioral - attendance, participation in the classroom and outside the classroom in extracurricular activities, compliance (or noncompliance) with school rules.

- Academic - students' grades, time spent on homework, credits earned, amount of accurate homework completed.

- Psychological - interest, support, attitudes toward school, sense of belonging and connection to school.

- Cognitive - goal-setting, motivation, and commitment to learning (Harris, 2011).

\section{Student Perceptions of Student Engagement}

- Gentilucci (2004) studied student perspectives on learning, which is very closely linked to student engagement. This study was conducted with elementary students based on data from 1978-1979 school year, validated as still current by a focus group held 20 years later.

- Results showed that elementary students think unchallenging curriculum, teacher misbehavior, overuse of cooperative learning, and inadequate instruction interfere with their learning.

- The students thought the major contributor of poor learning was inside the classroom, not outside. 


\section{The Knowing-Doing Gap}

- According to Pfeffer and Sutton's The Knowing-doing Gap: How Smart Companies Turn Knowledge Into Action (2000), this gap describes the disconnect between what people know and what they actually do to bring about change or improvement.

- This problem is broadly discussed within the realm of organizational theory (Pfeffer \& Sutton, 2000; Zheltoukhova, 2014; Sparks, 2009).

\section{Factors of Knowing-Doing Gap}

- Too much talk, not enough action

- Doing things the same way

- Not measuring the right things

- Detrimental competition

(Pfeffer \&Sutton, 2000) 


\section{Closing the Knowing-Doing Gap}

Recommended ways to counteract these problems including:

- understand the philosophy or the why before the how,

- knowing comes from doing and teaching others how,

- action counts more than talk,

- reward trying; avoid punishing mistakes or failures,

- avoid using fear as management style,

- collaborate and cooperate; do not compete,

- measure the things that promote culture and values,

- leadership creates culture that values knowledge building, sharing, and acting. (Pfeffer \& Sutton, 2000, p. 246)

\section{Knowing-Doing Gap in Education}

- Job experience will build teachers' knowledge, as trial and error is an often-used strategy.

- Pfeffer and Sutton call this tacit knowledge (2000), and indicate the action of doing as more beneficial than talking about doing, as immediate problems can be addressed in the context of the job. This also helps to shrink the knowing-doing gap in which nothing seems to get done. 


\section{Pedagogy - Cooperative Learning}

- Garcia and Pacheco state that cooperative learning is an, "interaction with different intellectual capabilities of students to improve the group learning and, by consequence, individual learning" (2010, p. 565).

- Vygotsky states, "in a cooperative scenario, the students interchange their ideas for coordinating them to achieve shared objectives. When the problems arise, the combination of activities with communication will conduce to learn" (as cited in Garcia \& Pacheco, 2010, p. 565).

- Gurbuz, Simsek, and Berber (as cited in Genç, 2016) discuss how the role of the teacher has transformed into a guide of student learning, rather than an imparter of information.

\section{Pedagogy - Learning Styles}

- Sousa states in his book, How the Brain Learns, only $20 \%$ of students are auditory learners; the other eighty percent learn either visually or kinesthetically (as cited in Tileston, 2011). Because of this reason, Tileston (2011) recommends that lecture as a teaching method should be limited to 15 minutes or less.

- Prensky states by the time students are 21 years of age, they will have played more than 10,000 hours of video games, sent and received 250,000 e-mails and text/instant messages, spent 10,000 hours talking on phone, watched more than 20,000 hours of television, and been exposed to 500,000 commercials (as cited in Tileston, 2011, p. 33). 


\section{Findings - Definition of Engagement}

- the most participants (seven) responded with the term "active", whether the student is actively participating, learning, thinking, or listening.

- Participant 2 stated their definition as, "Making sure everybody is involved and comprehending the information."

- Four participants cited "doing" and "focused".

- Participant 1 stated a student is engaged when he or she is "focused at the time on whatever's necessary, either focused on me giving notes, focused on working with a paper, focused on getting their homework done."

\section{Findings - Definition of Engagement}

- Participant 3 stated, "...they (students) need to have some pretty strict guidelines. That way they know what they're supposed to be doing and that they stay on task."

- Three participants said, "on task", "doing what is asked of them", and "hands-on".

- Two people stated that engagement also involves the "teacher listening" to the student.

- Other responses included, "student giving feedback", "free from distractions", "brainstorming", "problem solving together" and "making up problems". 


\section{Findings - Definition of Engagement}

- Participant 4 stated that student engagement is "when there is obvious connection between the teacher and the student on what the teacher is trying to teach."

- Participant 8 states, "They're in. They have bought in. They have completely and totally decided to believe in what you are doing at that moment....They're taking the journey with you."

\section{Findings - Engagement is not...}

- Participant 5 included, "sometimes student engagement isn't always eye contact and a nod, but... is evidence that they've actually gained the information that I'm trying to teach them and...can have quality discussions about what we've been discussing or what they're learning."

- Additionally, participant 10 stated that engagement is not, "just going through the motions."

- Participants 13 and 14 from the RPDC responded with what they termed cognitive engagement is, "not just activity, not just... moving, it's really about... thinking." 


\section{Findings - Factors of Student Engagement}

- The most common factor that contributes to student engagement cited by the participants was interest in the topic, activity, or class.

- Participant 9 said, "you have to make them interested in it. They have to have fun with it. They've got to enjoy it."

- Participant 4 said, "There has to be some sort of motivation for them to be engaged. There has to be a goal and objective they are reaching for...."

- Following up closely was the importance of a good teacher-student relationship and creating a positive classroom environment or culture.

\section{Findings - Factors of Student Engagement}

- Participant 5 said, "Classroom environment is probably the number one thing. You want a welcoming classroom environment where kids feel it's ok to ask questions, and to respond, and have classroom discussions... you have to have a comfortable environment and you also have to have a modicum of respect between students, student to student and between the student and the teacher."

- Relevance of the material to the student's life or to the real-world, things going on in a student's life, influences outside of school, as well as a student's mental or physical health, such as medications they take (or don't take), and lack of sleep. 


\section{Findings - Factors of Student Engagement}

- teaching methods, including classroom management, and teacher expectations of students and of themselves.

- Participant 11 stated "...the lesson, characteristics of the lesson itself"

- Participant 3 stated that in her classroom many of the engagement activities involve group work, and she always tries to have clear guidelines and assigned tasks for the students so everyone is participating and has a role in the activity. Additionally, she states that timelines that include checkpoints help to keep the students on task and focused on the activity because they know in advance what is expected of them.

- Participant 10 stated one factor is how the teacher presents the material, for example, "Is it just from the textbook? Is it something they get to physically be a part of?"

\section{Measures of Student Engagement}

- Majority said it included students talking or discussing material with their peers.

- Both administrators measured engagement as students' abilities to discuss or explain the topic, as well as articulate what they are doing and why.

- Teacher observation was a main way that teachers knew that students were engaged, like interpreting body language.

- Participant 2 stated that she evaluated student engagement by if, "they're doing what I asked them to do.... they're not distracted with anything, and you can hear if they are conversing with other students...about the subject matter." 


\section{Looks Can Be Deceiving}

- One third of the participants said that looks can be deceiving.

- Engagement may look different depending on the student, activity, or content area.

- Students can look like they are engaged by what they are doing, but may not be engaged in thinking.

- This can be checked or confirmed by the results of assessments, such as homework, projects, or performances (but often is too late).

\section{Importance of Engagement to Achievement}

- Eight people rated it as very important, or a five.

- Two additional people rated it a four or a five.

- One person rated it a three or a four.

- One person rated the importance as a three.

- One said it depended on the student, so no definitive rate was given. 
- The three or a four raters expressed that it depended on the student higher achievers, or more motivated, stating the link between engagement and achievement is less.

- Participant 3 stated, "for a child that's more average to lower level, I think it [student engagement] is very important for them... a lot of them don't get it unless they actually see it, or use their hands and make it happen."

- Another three or four rater said that students can be engaged in a classroom discussion, but may either choose not to do homework, or in the case of a test, they do not test well.

- If expectations or instructions for an assessment are not clear, then the level of engagement may not align with the student's ability to achieve.

- If a content area is particularly challenging for a student, they may be very engaged, but a letter grade of a $\mathrm{D}$ or $\mathrm{C}$ may be the best they can do in that content (Participant 1).

- According to Administrator 1, "just because students are engaged doesn't mean the content is what it needs to be."

- Both participants from the RPDC rated it as a five, very important to student achievement.

- One explanation for a five rating was that in the upper level classes where there is very high rigor, engagement is necessary or they will not be able to do the higher level cognitive thinking required (Participant 8). 


\section{Strategies to Increase Student Engagement}

- The most common response was incorporating student movement.

- Many recommended using a variety of teaching methods to maximize all students' learning styles.

- Some of those included hands-on activities, student choice, and student collaboration.

- Depending on the content area of the teacher interviewed, labs were mentioned as ways for students to apply learning hands-on, with the goal of connecting learning skills with real-world skills to increase relevance.

\section{Strategies to Increase Student Engagement}

- surprise, suspense, or novelty

- plan well-structured activities that were interesting or fun, reflect on the outcomes

- competition or games

- Participant 3 was quoted as saying, "They think they're just having fun when actually I'm sneaking in learning."

- Administrator 1 cautioned against playing versus learning - if objectives or standards are not being met through the competitions or games, then real learning is not happening even though the students seem engaged. 


\section{Strategies to Increase Student Engagement}

- Creating quality relationships, including teachers being engaged with and interested in the students and their lives.

- Administrator 1 stated the following about the importance of relationships, "...if the kids know that you care about them... and that you are interested in what they're interested in... or if you're interested in where they're coming from, then they are more willing to be engaged in what you're asking them to be engaged in. That relationship piece can be done in lots of ways, through content as well as other activities."

\section{Training in Engagement}

- Kagan Training (previously provided to the high school building)

- Content specific professional organizations

- Training or workshops provided by the professional organizations were sought by the teachers individually, rather than provided by the school district during a regular professional development day.

- graduate classes, their own reading and research, and workshops outside of the district

- No specific training outside of what the school district provided (beyond what they learned in their pre-service education programs).

- One teacher cited walking by another teacher's room and seeing what they were doing as a source of training or idea sharing. 


\section{Obstacles to Engagement (Student)}

- physical, emotional, and mental health of students. This could include lack of sleep, medical diagnosis (or lack of diagnosis), emotional well-being, or the ability to deal with life stressors.

- Participant 5 said "hunger, problems at home, hormones, emotional turmoil"

- Administrator 1 said, "I think right now l'm seeing it more and more as a trend than ever before with students, mental health issues being a huge distractor and causing a lot of problems with student engagement in the classroom."

- Participant 1 stated, "When they're falling asleep in class I don't take that personally, especially with more than one day. Something's going on. Something's wrong. I try to get to the bottom of why they're not paying attention. It's not who they want to be."

\section{Obstacles to Engagement (Student)}

- low student motivation or interest in the topic, or a low interest in general of school, often leading to student absences, not doing homework, or a lack of preparedness for class.

- Participant 4 stated, "they do not take homework home. It is hard to come back and talk about something if they haven't read it."

- Students' lives outside of school, as well as curricular and extracurricular activities Not only can activities create distractions, but they can limit their time and energy to do homework. 


\section{Obstacles to Engagement (Teacher)}

- lack of time to collaborate or share teaching ideas, as well as a lack of time to prepare engaging lessons/activities.

- teaching practices, presentation, and classroom management skills

- Participant 3 stated, “....we're not, as teachers, held accountable...for our lesson plans. I think a lot of times...teachers especially the ones that have been in the profession as long as I have...start getting relaxed and you wing it."

- The local RPDC (Participant 13) stated that an obstacle can be the "way that teachers present the information, with the goal being a dialogue with the students and not a monologue."

\section{Obstacles to Engagement (Teacher)}

- Participants noted that teachers who fail to build supportive and positive relationships with students have a harder time getting students engaged.

- Participant 5 noted, "some teachers...don't understand how to create the right type of relationship with the kids. To get students truly engaged, you can't be a dictator and you can't be their friend. So, it's finding that adult mentor relationship that's hard...." 


\section{Obstacles to Engagement (Environment)}

- Seven participants cited cellphones or entertainment technology in general.

- Participant 9 stated the following about student cellphone use, "I'm very frustrated with it. I think that it's distracting for them because they want to get right back to it.... I always thought that this would be a great tool.... It's kind of been all about playing games, and trying to hide it from the teacher."

- The structure of the classroom itself, including the size and physical setup. One teacher mentioned space as a major obstacle for a growing department that enrolls over a third of the student population with only three teachers (Participant 10).

- Diversity of a classroom regarding achievement, motivational, or developmental levels can hinder engagement.

- Participant 2 stated that because many of her activities are group performances, one student might have mastered the concept, but other students still need practice. The person who has mastered the skill can become disengaged because they are now bored.

\section{The Knowing-Doing Gap}

- Most common answer - lack of time to prepare and do engaging activities

- too many teacher responsibilities that took time away

- lack of accountability, both to themselves, and to the students and administration.

- Participant 1 said that a gap can occur when a teacher does not have a passion for their subject or the teaching career is not a good fit. She says, "I know some really nice people that are terrible teachers.... It's just not their gig." 


\section{The Knowing-Doing Gap}

- Participant 1 also mentioned that sometime a gap occurs unintentionally due to the physical or mental health of the teacher.

- The lack of collaboration or the time to share ideas with other teachers on best practices

- Participant 13 from the RPDC said, "... to close the knowing-doing gap, it helps for teachers to be in collaborative teams where they understand that there is mutual accountability."

- teacher resistance to change or a fear of failure if he or she tried something new and it did not work.

- Another theme to closing the gap was teacher practices, such as using a variety of teaching methods, teaching so students can understand, and reflecting on ways to improve.

\section{Discussion - Definition of Engagement}

- There was a wide variety of definitions of student engagement, that often overlapped. This is consistent with the numerous definitions in the literature, used by systems like Check \& Connect and the Instructional Practices Inventory. Many of the themes are the same, but have multiple names for often the same thing.

- The perspectives of the teachers usually matched some or most of the definitions in the literature, but very few spoke specifically about all the types. 


\section{Discussion - Factors of Engagement}

- Multiple factors were given as contributing to engagement, with many being repeated from one participant to another.

- When viewed through adult learning theory from the teacher's perspective, the factors can be categorized as whether the teacher has influence over the factor and can create and optimal learning environment that is within the teacher's control.

- For example, a teacher most likely cannot influence student sleeping habits or home life circumstances, but a teacher can determine the quality of relationship that he or she has with a student.

\section{Discussion - Measuring Engagement}

- Most respondents said it was not easy because thinking is not always visible. Often, we see the result of engagement, not the engagement itself. There are ways that teachers can estimate student engagement through body language, focus on task, and listening to them speak; but even these observations are not foolproof. Through experience, most teachers become better at the art of observation and realization. 


\section{Discussion - Measuring Engagement}

- Clearly, the ability of a student to tell someone coherently about the material learned is evidence of cognitive student engagement.

- According to Check \& Connect (2016), academic and behavioral engagement are more observable indicators and are easier to measure, compared to less observable indicators of cognitive and affective engagement which are harder to observe without knowing what a student is thinking. This confirms the findings that show there are multiple ways to measure, and it is not an easy task.

\section{Discussion - Strategies for Engagement}

- The strategies to increase student engagement mentioned by the participants in the field align with the examples given as descriptors for each category of engagement on the IPI scoring guide.

- Additional strategies given by the participants, like teacher passion and enthusiasm, movement in the classroom, positive teacherstudent relationships are all cited as research-based strategies as evidence of the importance of engagement (Valentine, 2009). 


\section{Discussion - Strategies for Engagement}

- Some teachers admitted frustration because they felt helpless and did not know what to do for students who were chronically disengaged, not from just that teacher's class, but from school in general.

- These students may find help in systems such as the Check \& Connect which is research-based and empirically proven to increase student engagement if implemented with integrity and continuity.

\section{Discussion - Training in Engagement}

- Most of the participants' responses about meaningful and helpful training in student engagement was sought after by the teachers themselves, or was made available through professional organizations that they belonged to.

- This also included graduate classes or workshops outside of the purview of the school district.

- Several mentioned the lack of relevancy or usefulness of district provided professional development to their own classroom or content, therefore, necessitating looking for other resources or professional development opportunities. 


\section{Discussion - Obstacles in Engagement}

- The obstacles were often identical to the factors. For example, interest in the topic was cited as a factor, therefore, a lack of interest in the topic was cited as an obstacle.

- Teacher-student relationships were cited as factors, and poor teacherstudent relationships were cited as possible obstacles.

- Again, teachers and schools often do not have much influence on student engagement obstacles, such as student health. These obstacles are not in the "circle of influence", and teachers need to focus on what they can influence in the classroom rather than what they cannot (Participant 13, RPDC).

\section{Discussion - Knowing-Doing Gap}

- Most of the responses indicated reasons that were seemingly out of the teacher's control. For example, lack of time, too many teacher responsibilities, lack of collaboration with colleagues, poor teacher health, and fear of failure. This indicated to the researcher that teachers want to minimize this gap and are trying their best to do a good job, but are overwhelmed at times which may lead to a knowing-doing gap. 


\section{Plans for the future}

- What is the goal for engagement at Nateville High School? Is it to decrease drop out rates? Is it to raise higher level thinking skills within each of the classrooms? Is it to raise motivation and get more students involved in all aspects of the school so they feel part of something bigger?

- I recommend all stakeholders having input into answering these questions.

- The answers to these essential questions will guide any future engagement focus (training, implementation, evaluation, and followup).

\section{References}

Alumni Association (2017). Nateville High School. Retrieved from http://.nhs-alumni.net/nhs_history.asp

Antaramian, S.P., Huebner, E.S., Hills, K.J., \& Valois, R.F. (2010). A dual-factor model of mental health: Toward a more comprehensive understanding of youth functioning. American Journal of Orthopsychiatry, $80(4), 462-472$.

Auken, P.V. (2012). Maybe it's both of us: Engagement and learning. Teaching Sociology. Sage Publications. 41 (2), 207-215. doi:10.1177/0092055x12457959

Bolman, L. G., \& Deal. T. E. (2008). Reframing organizations: Artistry, choice, and leadership (4 ${ }^{\text {th }}$ ed.). San Francisco, CA: Jossey-Bass.

Carini, R.M., Kuh, G.D., \& Klein, S.P. (2006). Student engagement and student learning: Testing the linkages. Research in Higher Education, 47(1), 1-32. doi:10.1007/s11162-005-8150-9

Caskey, M. M., \& Ruben, B. (2003). Research for awakening adolescent learning. The Education Digest, 36-38.

Check \& Connect Student Engagement Intervention. (2016). Emphasis on student engagement. Retrieved from University of Minnesota, Institute on Community Integration. http://checkandconnect.umn.edu/model/engagement.html

Corso, M. J., Bundick, M.J., Quaglia, R. J., \& Haywood, D. E. (2013). Where student, teacher, and content meet: Student engagement in the secondary school classroom. American Secondary Education, 41(3), 50-61.

Creswell, J.W. (2014). Research design: Qualitative, quantitative, and mixed methods approaches. Los Angeles, CA: Sage. 
Crotty, J.M. (2013, March). Motivation matters: 40\% of high school students chronically disengaged from school. Retrieved from https://www.forbes.com/sites /jamesmarshallcrotty/2013/03/13/motivationmatters-40-of-high-school-students-chronically-disengaged-from-school/\#3b5ddad06594

District Directory (2016). Nateville School District. Retrieved from http://natevillehs.com /UserFiles/Servers/Server_227053/File/Our\%20District/Staff\%20Directory/District\%20Directory\%202 016.pdf

Donnelly, M. (1987). At-risk students. ERIC digest. Eugene, OR: ERIC Clearinghouse on Educational Management. (ERIC Id. ED292171)

Eccles, J.S., \& Wigfield, A. (2002). Motivational beliefs, values, and goals. Annual Review of Psychology, 53, 109132.

Elbaz, F. (1981). The teacher's "practical knowledge": Report on a case study. Curriculum Inquiry, 11(1), 43-71.

Eldridge, J.S. (1998). Searching for meaning: Reflections on meaningful professional development. Curriculum Inquiry, 28(4), 491-502.

Erickson, G., Brandes, G.M., Mitchell, I., \& Mitchell, J. (2005). Collaborative teacher learning: Findings from two professional development projects. Teaching and Teacher Education, 21, 787-798.

Forneris, T., Camiré, M., \& Williamson, R. (2015). Extracurricular activity participation and the acquisition of developmental assets: Differences between involved and noninvolved Canadian high school students. Applied Developmental Science 19(1), 47-55. Doi:10.1080/10888691.2014.980580

Fullan, M. (1993). Change forces: Probing the depths of educational reform. Levittown, PA: The Falmer Press.

Garcia, I. A., \& Pacheco, C. L. (2010). Constructivism in Mexican elementary school education: Designing a platform for cooperative learning. Journal of Software, 5(6), 565-572.

Genç, M. (2016). An evaluation of the cooperative learning process by sixth-grade students. Research in Education, 95(1), 19-32.

Gentilucci, J.L. (2004). Improving school learning: The student perspective. The Educational Forum, 68, 133143.

Hall, J. (2016, September 16). Nateville school district receives $\$ 1$ million to build new preschool. St. Joseph News-Press. Retrieved from http://www.newspressnow.com

Harris, L. (2011). Secondary teachers' conceptions of student engagement: Engagement in learning or in schooling? Teaching and Teacher Education, 27, 376-386.

Kidwell, C. (2010). The impact of student engagement on learning. Leadership, Mar/Apr, 28-31.

Klem, A.M., \& Connell, J.P. (2004). Relationships matter: Linking teacher support to student engagement and achievement. Journal of School Health. 74(7) 262-272. 
Kuh, G.D. (2001). Assessing what really matters to student learning inside the national survey of student engagement. Change: The Magazine of Higher Learning, 33(3), 10-17. doi: 10.1080/00091380109601795

Lee, J., \& Shute, V. (2009). The influence of noncognitive domains on academic achievement in $K$-12 (ETS Research Rep. No. RR-09-34). Princeton, NJ: ETS

Long-Range Facilities Plan. (2006). Nateville School District. Retrieved from http://nateville.schoolwires.net /cms/lib6/MO01001842/ Centricity /Domain/28/Long\%20Range\%20Facilities\%20Plan.pdf

Merriam, S. B. (2009). Qualitative research: A guide to design and implementation. Hoboken, NJ: Jossey-Bass.

Merriam, S. B., \& Bierema, L.L. (2014). Adult learning: Linking theory and practice. San Francisco, CA: JosseyBass.

Mintzberg, H. (2005). The five basic parts of the organization. In J.M. Shafritz, J.S. Ott \& Y. Jang (Eds.), Classics of organizations theory (6th ed., pp. 219-230). Belmont, CA: Thomson Wadsworth. (Reprinted from The structure of organizations: A synthesis of research, by H. Mintzberg, 1979, Upper Saddle River, NJ: Prentice Hall)

Missouri Department of Elementary and Secondary Education. (n.d.). Missouri's Educator Evaluation System. Retrieved April 1, 2017, from https://dese.mo.gov/sites/default/files/00-TeacherEvaluationCompleteDoc.pdf

Missouri Department of Elementary and Secondary Education. (n.d.). District Annual Drop Out Rate for SavannahR3. Retrieved from https://mcds.dese.mo.gov/guidedinquiry/District\%20 and\%20 Building\%20Graduation\%20and\%20Dropout\%20Indic/District\%20Annual\%20Dropout\%20Rate.a spx

Missouri Department of Elementary and Secondary Education. (n.d.). District Annual Drop Out Rate for Missouri. Retrieved from https://mcds.dese.mo.gov/guidedinquiry/District\%20and\%20Bui Iding\%20Graduation\%20and\%20Dropout\%20Indic/District\%20Annual\%20Dropout\%20Rate.aspx

Nateville High School. (n.d.). District mission statement. Retrieved from http://hs.nateville.com/

Nateville School District. (2015, September). Board strategic priorities/goals/action steps. Retrieved from http://www.nateville.com /UserFiles/Servers/Server_227053/File /Nateville /District/ Documents /Board\%20of\%20Education/Goals\%20updated\%20September\%203.pdf

National Research Council and Institute of Medicine. (2004). Engaging schools: Fostering high school students' motivation to learn. Washington, DC: The National Academies Press.

Newmann, F.M. (Ed.). (1992). Student engagement and achievement in American secondary schools. New York, NY: Teachers College Press. 
Northouse, P. G. (2013). Leadership: Theory and practice. Los Angeles, CA: SAGE.

Pfeffer, J., \& Sutton, R. I. (2000). The knowing-doing gap: How smart companies turn knowledge into action. Boston, MA: HARVARD BUSINESS SCHOOL PRESS.

Rumberger, R.W. (2013). Poverty and high school dropouts: The impact of family and community poverty on high school dropouts. American Psychological Association. Retrieved from

http://www.apa.org/pi/ses/resources/indicator/2013/05/ poverty-dropouts.aspx

Sparks, D. (2009). Reach for the heart as well as the mind. JSD, 30(1), 48-54.

Thornberry, T., Moore, M., \& Christenson, R. (1985). The effect of dropping out of high school on subsequent criminal behavior. Criminology 23(1), 3-18.

Tileston, D.W. (2011). 10 Best teaching practices: How brain research and learning styles define teaching competencies. Thousand Oaks, CA: Corwin.

Torpey, E., \& Watson, A. (2014, September). Education level and jobs: Opportunities by state. Bureau of Labor Statistics. Retrieved from https

U.S. Department of Education. (2017). Fast facts. National Center for Education Statistics. Retrieved from http://nces.ed.gov/fastfacts/

Willms, J.D., Friesen, S. \& Milton, P. (2009). What did you do in school today? Transforming classrooms through social, academic and intellectual engagement. (First National Report) Toronto: Canadian Education Association. Retrieved from ERIC database.

Zheltoukhova, K. (2014). Leadership in organizational practice: Closing the knowing-doing gap. Strategic HR Review, 13(2), 69-74. doi: 10.1108/SHR-10-2013-0093 


\title{
SECTION FIVE: CONTRIBUTION TO SCHOLARSHIP
}

\section{Target Journal}

The target journal for publication is the Educational Researcher which is a publication of the American Educational Research Association.

\section{Rationale for this Target}

Educational Researcher is a peer-reviewed journal that publishes a wide variety of topics in the education and associated fields with the purpose of making available prominent new research dealing with a vast array of educational issues.

\author{
Abstract \\ Introductory paragraph \\ Literature review \\ Background info \\ Conceptual framework \\ Research questions \\ Methods \\ Findings \\ Implications \\ (Up to 5 figures or tables, up to 40 references, less than 5000 words)
}

Outline of Proposed Contents

\section{Plan for Submission}

Who: ScholarOne Manuscripts

When: Fall of 2017

How: ScholarOne Manuscripts portal at https://mc.manuscriptcentral.com/edr 


\section{A CASE STUDY OF TEACHERS' PERCEPTIONS OF STUDENT ENGAGEMENT IN ONE MIDWEST RURAL HIGH SCHOOL}

Dasha Davis received her Doctorate in Educational Leadership and Policy Analysis from the University of Missouri - Columbia. Dasha's mission is to serve as an educational leader through her expertise, experience, and passion for helping others succeed. 


\title{
A CASE STUDY OF TEACHERS' PERCEPTIONS OF STUDENT \\ ENGAGEMENT IN ONE MIDWEST RURAL HIGH SCHOOL
}

\begin{abstract}
This qualitative study examines teachers' perceptions of student engagement in one Midwest rural high school. The researcher examined teacher, administrator, and members of the regional professional development center responses through interviews regarding engagement definitions, factors, obstacles, importance to achievement, training, strategies, and teacher knowing-doing gap. Definitions of engagement included what students were doing, and what they were thinking in relation to the academic focus. Factors, such as teacher relationships, student interest, and relevance sometimes turned into obstacles if there were poor outcomes of the factors. Themes of strategies included using a variety of teaching practices for all learning styles, and structure or choice of learning activities.
\end{abstract}

Keywords: student engagement, engagement, student achievement, knowing doing gap, student interest, school drop-outs, obstacles to engagement, engagement definition, engagement systems

\section{Introduction}

With the myriad of benefits of quality educational systems, there is an everincreasing push for higher standards and achievement for public school students in the United States who score well below the top countries on the Programme for International Student Assessment (PISA) tests (OECD, 2016). Research shows that student engagement is one factor that contributes to higher student achievement, particularly within subgroups (Lee \& Shute, 2009; Antaramian, Huebner, Hills, \& Valois, 2010). Antaramian, Huebner, Hills, and Valois stated, "students who are more engaged in school tend to have higher grades and better performance on standardized tests" (2010, p. 464).

Low student engagement can affect all groups of students. Forty percent of students at the high school level are not engaged with the content or academic activities within the classroom setting (Crotty, 2013). Others think it may be as high as $60 \%$ (Klem 
\& Connell, 2004, p. 262). In fact, the number of disengaged students increases as they progress from elementary, middle, and high schools (Corso, Bundick, Quaglia, and Haywood, 2013; Klem \& Connell, 2004; Eccles \& Wigfield, 2002).

\section{Problem Statement}

The problem of low student engagement can lead to numerous negative outcomes (Harris, 2011). Willms states that low student engagement leads to $25 \%$ of students' sense of low belonging, and 20\% regularly absent from school (Willms, 2009). The National Research Council and Institute of Medicine (2004) reports "dropping out of school is for many students the last step in a long process through which students become disengaged from school" (p. 24). Corso et al., (2013) stated that, "Dropping out is highly likely to have serious negative long-term consequences, such as difficulty finding employment and reduced quality of life" (p. 51). Even when employed those without a high school diploma will make an average of $\$ 15,000$ less than the median wage of someone with a high school diploma (Torpey \& Watson, 2014), often plunging them into poverty (Rumberger, 2013). Thornberry, Moore, and Christenson (1985) concluded that drop-outs have more incidences of criminal activity leading to incarceration than peers who did not drop out. Poverty, incarceration, and poor health are but a few of the detrimental outcomes that often occur to those that drop out of school.

\section{Purpose of Study}

Teachers' attitudes, along with the ways they think and learn influence students in the classroom. By examining teachers' perspectives on student engagement, the data will provide an opportunity to share and reflect on the problems and solutions in engaging students. By increasing engagement in the classroom, students benefit through an increase in achievement, therefore, increasing the number of students that stay in school. 
By understanding more completely how educators view the different types of engagement, educators can use this knowledge to set goals for engagement to meet the needs of a $21^{\text {st }}$ century learner in a compulsory setting.

\section{Theoretical Framework}

To understand the literature behind this study, the theoretical framework of adult learning theory will be examined. Viewed within the construct of the education system, one way that adult learning theory is utilized is through teacher professional development and growth. Educators want and need more meaningful, purposeful, and quality professional development that not only helps them with their teaching, but also "affirm[s] their practice" (Eldridge, 1998, p. 500). Fullen states that "teachers' jobs are more complex than ever before. They must respond to the needs of a diverse and changing population, a rapidly changing technology in the workplace, and demands for excellence from all segments of society" (as cited in Eldridge, 1998, p. 492).

Obtaining and maintaining a teacher's ability to meet multidimensional learner needs is a complex issue. By understanding adult learning theory, teachers and administrators can use professional development to increase teacher capacity and efficacy not only with student engagement per this study.

There are some major principles of adult learning that are different than child learning. Merriam and Bierema (2014) wrote that adult learners have numerous roles and responsibilities in addition to being a student learner. Secondly, adults bring more life experiences into the learning sphere which provides a more robust basis of prior knowledge and context to learning. As a result, the motivations for adult learning vary as the person desires to improve their life, perhaps for a job, personal, or social purposes (Merriam \& Bierema, 2014). 


\section{Research Question}

This case study is designed to answer the following overarching research question: What are teachers' perceptions of student engagement in one rural Midwest public high school?

\section{Research Method and Data Collection}

The methods of data collection were interviews, walk-through classroom observations, interviews, and a literature review. Classroom walk-through observations were conducted with those teachers who agreed to be interviewed, in hopes that some context would be provided with the observation and the interview. The researcher maintained a non-participant role in the observation (Creswell, 2014) and used the descriptive method of note-taking outlined by Emerson, Fretz, and Shaw (2011). The researcher took notes on any action, dialogue, and behavior in the classroom. This was conducted in an unstructured way, however, making note on levels of engagement as the focus of the study.

The methodology used for this study was qualitative (Creswell, 2014; Merriam, 2009) in which researcher was the primary data gatherer and used an inductive process to “establish comprehensive themes” (Creswell, 2014, p. 186; Merriam, 2009). Since teachers' experiences and thoughts were gathered as data, a qualitative focus was the most appropriate as the method centers on the meaning from participants, not the meaning of the author (Creswell, 2014; Merriam, 2009).

Interviews were conducted with teachers, administrators, and local Regional Professional Development Center (RPDC) representatives for which a purposeful sample was chosen. Interviews were done individually so not to distract the interviewees by the presence of another person, and to protect the privacy of respondents (Fink, 2013). 


\section{Data Analysis}

Researcher determined emergent themes from the transcriptions of the interviews, then coded the themes (Merriam, 2009; Creswell, 2014). Once this process was completed, researcher turned to a deductive process and went back to the data to determine if additional literature needed gathered to support themes. Special attention was given to the fact that the research was considered "backyard" research, coined by Glesne \& Peshkin in 1992 (as cited in Creswell, 2014, p. 188) in which the setting was the immediate work environment of the researcher.

\section{Findings}

Student Engagement is a comprehensive concept in which the participants had varying definitions and ideas on how to define, measure, and increase it. Through interviews with teachers, administrators, and the local RPDC, all categories of academic, behavioral, cognitive, and affective engagement, as defined by the Check \& Connect system (Check \& Connect Student Engagement Intervention, 2016) were discussed. Their responses were based on their educational experiences which aligned with previous research studies, but opportunities still exist to expand the working definition of engagement within the classroom and school setting.

\section{Definition of Student Engagement}

When participants were asked how they defined student engagement, the most participants (seven) responded with the term "active" as the predominate descriptor, whether the student is actively participating, learning, thinking, or listening. Participant 2 stated their definition as, "Making sure everybody is involved and comprehending the information." Four participants cited "doing" and "focused". Participant 1 stated a student is engaged when he or she is "focused at the time on whatever's necessary, either 
focused on me giving notes, focused on working with a paper, focused on getting their homework done.” Participant 3 stated, “...they (students) need to have some pretty strict guidelines. That way they know what they're supposed to be doing and that they stay on task." Three participants said, "on task", "doing what is asked of them", and "hands-on". Other responses included, "student giving feedback", and "free from distractions". Additional responses included, "brainstorming", "problem solving together" and "making up problems". Participant 4 stated that student engagement is "when there is obvious connection between the teacher and the student on what the teacher is trying to teach." Two people stated that engagement also involves the "teacher listening" to the student. Participant 8 states, “They're in. They have bought in. They have completely and totally decided to believe in what you are doing at that moment....They're taking the journey with you."

In addition to responses on what student engagement is, several explained what student engagement is not. Participant 5 included,

Sometimes student engagement isn't always eye contact and a nod, but... is evidence that they've actually gained the information that I'm trying to teach them and...can have quality discussions about what we've been discussing or what they're learning.

Additionally, participant 10 stated that engagement is not, "just going through the motions." Participants 13 and 14 from the RPDC responded with what they termed cognitive engagement, "not just activity, not just... moving, it's really about... thinking."

\section{Factors Contributing to Student Engagement}

By far the most common factor that contributes to student engagement cited by the participants was interest in the topic, activity, or class. Participant 9 said, "you have to 
make them interested in it. They have to have fun with it. They've got to enjoy it." Participant 4 said, "There has to be some sort of motivation for them to be engaged. There has to be a goal and objective they are reaching for...." Following up closely was the importance of a good teacher-student relationship and creating a positive classroom environment or culture. Participant 5 said,

Classroom environment is probably the number one thing. You want a welcoming classroom environment where kids feel it's ok to ask questions, and to respond, and have classroom discussions.... you have to have a comfortable environment and you also have to have a modicum of respect between students, student to student and between the student and the teacher.

Another common theme was relevance of the material to the student's life or to the real-world. Another response included things going on in a student's life, influences outside of school, as well as a student's mental or physical health, such as medications they take (or don't take), and lack of sleep.

Additional factors to student engagement were teacher methods, including classroom management, and teacher expectations of students and of themselves. Participant 11 stated "...the lesson, characteristics of the lesson itself," is a factor to student engagement. Participant 3 stated that in her classroom many of the engagement activities involve group work, and she always tries to have clear guidelines and assigned tasks for the students so everyone is participating and has a role in the activity. Additionally, she states that timelines that include checkpoints help to keep the students on task and focused on the activity because they know in advance what is expected of them. Participant 10 stated one factor to student engagement is how the teacher presents 
the material, for example, "Is it just from the textbook? Is it something they get to physically be a part of?"

\section{Measures of Student Engagement}

When participants were asked what student engagement looked like, the majority said it included students talking or discussing material with their peers. Students who could discuss or explain the topic, as well as articulate what they are doing and why, was and important way in which both administrators measured student engagement. Teacher observation was a main way that teachers knew that students were engaged. Interpreting body language was a way to get non-verbal feedback from the students. Participant 2 stated that she evaluated student engagement by if, "they're doing what I asked them to do... they're not distracted with anything, and you can hear if they are conversing with other students...about the subject matter." Many said that they look to see if students are paying attention.

Nonetheless, one third of the participants said that looks can be deceiving. To take this concept a step further, engagement may look different depending on the student, activity, or content area. Students can look like they are engaged by what they are doing, but may not be engaged in thinking. This can be checked or confirmed by the results of assessments, such as homework, projects, or performances.

\section{Importance of Student Engagement to Student Achievement}

When participants were asked about how important he or she thought student engagement was to student achievement on a scale of one to five, with five being the most important, eight people rated it as very important, or a five. Two additional people rated it a four or a five. One person rated it a three or a four. One person rated the 
importance as a three, and one said it depended on the student, so no definitive rate was given.

The participants that rated it a three or a four expressed that it depended on the student, explaining that some students are higher achievers or are motivated to achieve and the link between engagement and achievement is less. Participant 3 stated, "for a child that's more average to lower level, I think it [student engagement] is very important for them... a lot of them don't get it unless they actually see it, or use their hands and make it happen." An additional explanation for a three or four rating is that students can be engaged in a classroom discussion, but may either choose not to do homework, or in the case of a test, they do not test well. Furthermore, if expectations or instructions for an assessment are not clear, then the level of engagement may not align with the student's ability to achieve. Also, if a content area is particularly challenging for a student, they may be very engaged, but a letter grade of a D or C may be the best they can do in that content (Participant 1). Finally, according to Administrator 1, "just because students are engaged doesn't mean the content is what it needs to be."

Both participants from the RPDC rated it as a five, very important to student achievement. One explanation for a five rating was that in the upper level classes where there is very high rigor, engagement is necessary or they will not be able to do the higher level cognitive thinking required (Participant 8).

\section{Strategies to Increase Student Engagement}

Many of the strategies mentioned for increasing student engagement were suggestions for the teachers (by the teachers) on teaching methods, classroom management, and overall pedagogical skill. The most common response to suggested strategies to increase student engagement was incorporating student movement. Many 
recommended using a variety of teaching methods to maximize all students' learning styles. Some of those included hands-on activities, student choice, and student collaboration. Depending on the content area of the teacher interviewed, labs were mentioned as ways for students to apply learning hands-on, with the goal of connecting learning skills with real-world skills to increase relevance.

Using the element of surprise, suspense, or novelty was recommended. Several felt it was important to plan well-structured activities that were interesting or fun, as well to reflect on the outcomes to better determine what worked, what did not work, and how to improve in the future. Several participants cited competition or games to motivate students to engage. Participant 3 was quoted as saying, "They think they're just having fun when actually I'm sneaking in learning." Administrator 1 cautioned against playing versus learning, in that if objectives or standards are not being met through the competitions or games, then real learning is not happening even though the students seem engaged.

Creating quality relationships with students was also cited as important to maintaining high student engagement, including teachers being engaged with and interested in the students and their lives. Administrator 1 stated the following about the importance of relationships,

...if the kids know that you care about them... and that you are interested in what they're interested in... or if you're interested in where they're coming from, then they are more willing to be engaged in what you're asking them to be engaged in. That relationship piece can be done in lots of ways, through content as well as other activities. 


\section{Training in Student Engagement}

When asked about specific training the participants have had with student engagement, they all answered Kagan Training which was provided to the high school building involved in this case study by the school district the prior year. Several others mentioned resources or training that they had received through professional organizations to which they belonged within their content area. Training or workshops provided by the professional organizations were sought by the teachers individually, rather than provided by the school district during a regular professional development day. Several mentioned graduate classes, their own reading and research, and workshops outside of the district that provided them with additional training for student engagement. Still, some said that they have not had any specific training outside of what the school district provided (beyond what they learned in their pre-service education programs). One teacher cited walking by another teacher's room and seeing what they were doing as a source of training or idea sharing.

\section{Obstacles to Student Engagement}

The obstacles fit into three major themes, student, teacher, and environmentcentered. One example of a student-centered obstacle included the physical, emotional, and mental health of students. This could include lack of sleep, medical diagnosis (or lack of diagnosis), emotional well-being, or the ability to deal with life stressors. Participant 5 said "hunger, problems at home, hormones, emotional turmoil" can all be obstacles to student engagement.

Administrator 1 said, "I think right now I'm seeing it more and more as a trend than ever before with students, mental health issues being a huge distractor and causing a lot of problems with student engagement in the classroom." Participant 1 stated, 
When they're falling asleep in class I don't take that personally, especially with more than one day. Something's going on. Something's wrong. I try to get to the bottom of why they're not paying attention. It's not who they want to be.

Additionally, another student-centered obstacle was low student motivation or interest in the topic, or a low interest in general of school, often leading to student absences, not doing homework, or a lack of preparedness for class. Participant 4 stated, "they do not take homework home. It is hard to come back and talk about something if they haven't read it." Students' lives outside of school, as well as curricular and extracurricular activities affected student engagement as possible distractors to student engagement in the classroom. Not only can activities create distractions, but they can limit their time and energy to do homework.

Teacher-centered obstacles included lack of time to collaborate or share teaching ideas, as well as a lack of time to prepare engaging lessons/activities. Furthermore, teaching practices, presentation, and classroom management skills were all mentioned as possible obstacles for student engagement. Participant 3 stated, “...we're not, as teachers, held accountable...for our lesson plans. I think a lot of times...teachers especially the ones that have been in the profession as long as I have...start getting relaxed and you wing it." The local RPDC (Participant 13) stated that an obstacle can be the "way that teachers present the information, with the goal being a dialogue with the students and not a monologue." Participants noted that teachers who fail to build supportive and positive relationships with students have a harder time getting students engaged. Participant 5 noted, 
some teachers...don't understand how to create the right type of relationship with the kids. To get students truly engaged, you can't be a dictator and you can't be their friend. So, it's finding that adult mentor relationship that's hard....

Environmental obstacles to student engagement mentioned by seven of the interviewed participants were cellphones or entertainment technology in general. Participant 9 stated the following about student cellphone use,

I'm very frustrated with it. I think that it's distracting for them because they want to get right back to it.... I always thought that this would be a great tool.... It's kind of been all about playing games, and trying to hide it from the teacher.

The structure of the classroom itself, including the size and physical setup of the class were also cited as obstacles. Additionally, the diversity of a classroom regarding achievement, motivational, or developmental levels can hinder engagement. Participant 2 stated that because many of her activities are group performances, one student might have mastered the concept, but other students still need practice. The person who has mastered the skill can become disengaged because they are now bored. Even though only one teacher mentioned space as an obstacle, it was a major obstacle for a growing department that enrolls over a third of the student population with only three teachers (Participant 10).

\section{The Knowing-Doing Gap}

Participants were asked if they agreed or disagreed with research that shows there is a knowing-doing gap among teachers as it relates to student engagement in the classroom. The lack of time to prepare and do engaging activities within the scope of the curriculum requirements was the most commonly answered reason for a possible knowing-doing gap. One idea that emerged regarding the lack of time, was too many 
teacher responsibilities that took time away from preparing lessons and creating the opportunities that would provide valuable real-world experiences. Another theme that participants mentioned was the lack of accountability, both to themselves, and to the students and administration. Participant 1 said that a gap can occur when a teacher does not have a passion for their subject or the teaching career is not a good fit. She says, "I know some really nice people that are terrible teachers.... It's just not their gig." Participant 1 also mentioned that sometime a gap occurs unintentionally due to the physical or mental health of the teacher. The lack of collaboration or the time to share ideas with other teachers on best practices was another theme. Participant 13 from the RPDC said, “... to close the knowing-doing gap, it helps for teachers to be in collaborative teams where they understand that there is mutual accountability." Yet another theme was teacher resistance to change or a fear of failure if he or she tried something new and it did not work. Another theme to closing the gap was teacher practices, such as using a variety of teaching methods, teaching so students can understand, and reflecting on ways to improve.

\section{Discussion}

The results of this study indicate a multitude of ideas on the definition of student engagement, obstacles, and ways to improve student engagement. Knowing what teachers, administrators, and experts from the RPDC think about engagement will inform future teaching practices and training to ultimately increase student engagement and hopefully, drive an increase in student learning and success.

\section{Definition of Engagement}

When participants were asked what they thought the definition of student engagement was, there was a wide variety of definitions that often overlapped. Many 
participants focused on one or two of the subtypes described in the Check \& Connect system: academic, behavioral, cognitive, and affective (Check \& Connect Student Engagement Intervention, 2016). This seems to align with research in which there is no definitive definition of engagement, only categories that often overlap each other depending on the purpose of engagement. For example, the Check \& Connect System targets students who are chronically disengaged and at-risk of dropping out. This system uses a definition of engagement that focuses on the whole student, yet the Instructional Practices Inventory focuses on higher-level thinking of learner engagement to raise student achievement (Valentine, 2005). Even these two major empirically researched systems do not agree on a common definition of student engagement.

\section{Factors for Student Engagement}

Each participant in the study cited multiple factors contributing to engagement, with many being repeated from one participant to another. When these factors are viewed through adult learning theory from the teacher's perspective, the factors can be categorized as whether the teacher has influence over the factor and can create and optimal learning environment that is within the teacher's control. For example, a teacher most likely cannot influence student sleeping habits or home life circumstances, but a teacher can determine the quality of relationship that he or she has with a student. The teacher does have influence over such things as teacher-student relationships, and must focus on factors that he or she can do something about.

\section{Measuring Student Engagement}

Most respondents said that measuring cognitive engagement was not easy because thinking is not always visible. Often, we see the result of engagement, not the engagement itself. There are ways that teachers can estimate student engagement 
through body language, focus on task, and listening to them speak; but even these observations are not foolproof. Through experience, most teachers become better at the art of observation and realization.

Clearly, the ability of a student to tell someone coherently about the material learned is evidence of cognitive student engagement. According to Check \& Connect, academic and behavioral engagement are more observable indicators and are easier to measure, compared to less observable indicators of cognitive and affective engagement which are harder to observe without knowing what a student is thinking. This confirms the findings that show there are multiple ways to measure, and it is not an easy task.

Depending on the purpose of engagement, how it is measured will vary. If the purpose is more higher level thinking, then a valid measuring tool could be the Instructional Practices Inventory (IPI) developed by Painter and Valentine (Valentine, 2005). Another resource to measure engagement mentioned by the RPDC was the book, Making Thinking Visible by Ritchhart, Church, and Morrison (2011) as one way to be familiar with the 'look fors' that show higher level thinking and deeper learning. There is an opportunity for further edification on how to measure engagement, based on an agreed upon definition and purpose.

\section{Strategies to Increase Student Engagement}

The strategies to increase student engagement mentioned by the participants in the field align with the examples given as descriptors for each category of engagement on the IPI scoring guide. Additional strategies given by the participants, like teacher passion and enthusiasm, movement in the classroom, positive teacher-student relationships are all cited as research-based strategies as evidence of the importance of engagement 
(Valentine, 2009). The responses to this part of the study align with the research of engagement.

Some teachers admitted frustration because they felt helpless and did not know what to do for students who were chronically disengaged, not from just that teacher's class, but from school in general. These students may find help in systems such as the Check \& Connect which is research-based and empirically proven to increase student engagement if implemented with integrity and continuity.

\section{Teacher Training in Engagement}

Most of the participants' responses about meaningful and helpful training in student engagement was sought after by the teachers themselves, or was made available through professional organizations that they belonged to. This also included graduate classes or workshops outside of the purview of the school district. Several mentioned the lack of relevancy or usefulness of district provided professional development to their own classroom or content, therefore, necessitating looking for other resources or professional development opportunities.

\section{Obstacles to Engagement}

The obstacles to engagement cited by the participants were often identical to the factors. For example, interest in the topic was cited as a factor, therefore, a lack of interest in the topic was cited as an obstacle. Teacher-student relationships were cited as factors, and poor teacher-student relationships were cited as possible obstacles. Again, teachers and schools often do not have much influence on student engagement obstacles, such as student health. These obstacles are not in the "circle of influence", and teachers need to focus on what they can influence in the classroom rather than what they cannot (Participant 13, RPDC). 


\section{The Knowing-Doing Gap}

Participants were not very familiar with this concept, requiring the researcher to further explain. Most of the responses indicated reasons that were seemingly out of the teacher's control. For example, lack of time, too many teacher responsibilities, lack of collaboration with colleagues, poor teacher health, and fear of failure. This indicated to the researcher that teachers want to minimize this gap, do a good job, and want their students to learn, which supports Dufour and Marzano who stated,

We do not... believe that the problems of public schools have been caused by the unwillingness of educators to work hard or because they are disinterested in the well-being of their students. The problem, instead, is that they have lacked the collective capacity to promote learning for all students in the existing structures and cultures of the systems in which they work (p. 15, 2011).

\section{Limitations}

Limitations to this research study involve the small size of the study, limited time allocated, as well as the time of the school year (last month of school) that the study was done. Additionally, there is a limited generalizability of a qualitative case study (Merriam, 2009). The researcher is a teacher and has many shared experiences inside and outside of the classroom with the participants that were interviewed, and brings personal biases based on experience and education into the interpretation of the findings (Merriam, 2009). Finally, the researcher is a faculty member of the school in the case study, so maintaining positive relationships, as well as employment was essential.

\section{Delimitations}

The researcher did not interview anyone within the researcher's own department due to potential bias. Additionally, no other schools within the district were chosen as 
population samples, due to time constraints and easier coordination of scheduling with the researcher's schedule. Finally, only three males were asked to participate in the interviews due to the limited number of male teachers, and the desire of the researcher to interview many different departments - several male teachers were in the same department.

\section{Assumptions}

The researcher assumes the participants were honest and forthcoming with their input with the intention of furthering scholarship, rather than ulterior motives that would skew the data results. Also, it was assumed that all participants were willing participants and felt no obligation to participate in the study. Finally, it is assumed that the participants trusted the researcher to carry out the study with "integrity and competence" (Merriam, 2009, p. 228).

\section{Implications for Future Practices and Research}

Further research is needed to expand on teacher perspectives of student engagement in elementary and middle levels, as well as in other areas of the country and world. Do teachers' perceptions of student engagement differ based on the general age of student taught? Also, are teachers' perspectives of engagement influenced by their own adult learning criteria and how the teacher learns best? These questions were outside of the purview of this research study. By understanding how teachers think and learn, insight is provided to other teachers, administrators, and those in charge of teacher training on how to build teacher capacity and efficacy. It is recommended that results from this study, as well as others like it, be used to bring additional awareness and knowledge of student engagement with its many facets to the forefront of teachers' minds. Educational decisions can be guided by having a better understanding on how 
students are engaged and how it affects student learning. Increasing engagement, therefore, increases student opportunities for achievement and success.

As far as the building in which the case study was conducted, the researcher recommends a presentation of the findings and discussion to open a dialogue with administrators on how to best use this information to improve student engagement and achievement. Based on the findings, a common and agreed upon definition of engagement must be established with input from teachers and administrators based on the building goals. It is important that the definition of engagement include teachers to promote buy-in for the fidelity of improving engagement. Once that is established, administrators and teachers should be trained on the subtypes of engagement, as well as research-based pedagogy that leads to an increase in engagement. Most importantly, when implementing a new initiative, systems need to be created for accountability and follow-up measures to ensure continuity and integrity of the improvement initiative. 


\section{References}

Antaramian, S.P., Huebner, E.S., Hills, K.J., \& Valois, R.F. (2010). A dual-factor model of mental health: Toward a more comprehensive understanding of youth functioning. American Journal of Orthopsychiatry, 80(4), 462-472.

Check \& Connect Student Engagement Intervention. (2016). Emphasis on student engagement. Retrieved from University of Minnesota, Institute on Community Integration. http://checkandconnect.umn.edu/model/engagement.html

Corso, M. J., Bundick, M.J., Quaglia, R. J., \& Haywood, D. E. (2013). Where student, teacher, and content meet: Student engagement in the secondary school classroom. American Secondary Education, 41(3), 50-61.

Creswell, J.W. (2014). Research design: Qualitative, quantitative, and mixed methods approaches. Los Angeles, CA: Sage.

Donnelly, M. (1987). At-risk students. ERIC digest. Eugene, OR: ERIC Clearinghouse on Educational Management. (ERIC Id. ED292171)

Dufour, R., \& Marzano, R.J. (2011). Leaders of learning: How district, school, and classroom leaders improve student achievement. Bloomington, IN: Solution Tree press.

Eccles, J.S., \& Wigfield, A. (2002). Motivational beliefs, values, and goals. Annual Review of Psychology, 53, 109-132.

Eldridge, J.S. (1998). Searching for meaning: Reflections on meaningful professional development. Curriculum Inquiry, 28(4), 491-502.

Emerson, R.M., Fretz, R.I., \& Shaw, L.L. (2011). Writing ethnographic fieldnotes. $\left(2^{\text {nd }}\right.$ ed.). Chicago, IL: The University of Chicago Press. 
Fink, A. (2013). How to conduct surveys: A step-by-step guide (5th ed.) Thousand Oaks, CA: SAGE.

Fullan, M. (1993). Change forces: Probing the depths of educational reform. Levittown, PA: The Falmer Press.

Harris, L. (2011). Secondary teachers' conceptions of student engagement: Engagement in learning or in schooling? Teaching and Teacher Education, 27, 376-386.

Klem, A.M., \& Connell, J.P. (2004). Relationships matter: Linking teacher support to student engagement and achievement. Journal of School Health. 74(7) 262-272.

Kuh, G.D. (2001). Assessing what really matters to student learning inside the national survey of student engagement. Change: The Magazine of Higher Learning, 33(3), 10-17. doi: 10.1080/00091380109601795

Lee, J., \& Shute, V. (2009). The influence of noncognitive domains on academic achievement in K-12 (ETS Research Rep. No. RR-09-34). Princeton, NJ: ETS

Merriam, S. B. (2009). Qualitative research: A guide to design and implementation. Hoboken, NJ: Jossey-Bass.

National Research Council and Institute of Medicine. (2004). Engaging schools: Fostering high school students' motivation to learn. Washington, DC: The National Academies Press.

Newmann, F.M. (Ed.). (1992). Student engagement and achievement in American secondary schools. New York, NY: Teachers College Press.

OECD (2016), Reading performance (PISA) (indicator). doi: 10.1787/79913c69-en Ritchhart, R., Church, M., \& Morrison, K. (2011). Making thinking visible: How to promote engagement, understanding, and independence for all learners. San Francisco, CA: Jossey-Bass. 
Valentine, J. (2005). Instructional practices inventory: A process for profiling student engaged learning for school improvement. Middle Level Leadership Center. University of Missouri. Retrieved from http://mllc.missouri.edu/Upload\%20AreaDocs/IPI\%20Manuscript\%208-05.pdf

Valentine, J. (2009). Evidence re the importance of engagement. Pdf. Copy in possession of researcher. 


\section{SECTION SIX - SCHOLARLY PRACTITIONER REFLECTION}

The doctorate journey, including the dissertation, has affected many areas of my life including my role as an educational leader and scholar. To discuss these effects, the whole program must be considered. The dissertation was not completed in a vacuum. The successful completion of the dissertation would not have been possible without every other experience throughout these last four years that prepared me. This program has guided me in connecting educational theory and practice through coursework, projects, colleague collaboration, and a Dissertation in Practice with the anticipation of DOING great things with my new knowledge and experience. The knowledge that I have gained about leadership and scholarship will inform my practice in the future.

\section{Leader}

Through high-quality synthesis of knowledge and experience gained from the Educational Leadership and Policy Analysis program, culminating in a dissertation in practice, this paper will examine two content areas and draw connections between theory and practice as it relates to my personal experience as an educational leader in the past, as well as the future. These content areas are the following: leadership theory and practice, and organizational analysis.

Leadership theories and approaches are as numerous as there are planned viewers of the total solar eclipse in August 2017. I propose that these theories are not mutually exclusive. A skilled and knowledgeable leader can adapt to the situation, people, or task to ensure effectiveness (Goleman, 2011) by changing leadership approaches. I have connected the following basic components of leadership traits, skills, and style approaches to my personal leadership development. 
Traits are defined as characteristics obtained through birth. These range from intelligence, motivation, problem solving capabilities, to integrity (Northouse, 2013). While these could certainly help a leader maneuver around daily challenges, these traits on their own do not make or break a leader. Traits contribute to a leader's effectiveness, but they can also be affected by experience and development. So, traits can change, but are mostly static. I have demonstrated all the above trait characteristics, which serve as a backbone to leadership potential. I feel like these factors were taken into consideration when applicants were chosen for the ELPA program to determine capabilities for successful completion of the program, as well as future success as a leader and scholar.

In addition to traits, effective leaders learn and develop skills over time. Northouse (2013) states that "skills and knowledge of leaders are shaped by their career experiences as they address increasingly complex problems in the organization" (p. 55). This can be examined through the tasks required of the ELPA program, starting with the annotations that we did before our first summer session started. I look at those annotations now and remember how difficult they were for me, not knowing what I was doing nor having done anything similar before. As I have progressed through the program, and now almost finished with my dissertation, the amount of skills I have learned and developed during this time is incomprehensible to me. Effective leaders can draw from both trait and skill resources, not only from themselves, but from the strengths of others. During the process of writing my dissertation, my cohort served as a support team in which I could ask anything and they were more than willing to share their scholarly skills.

Leadership style focuses on behaviors of both task and relationships (Northouse, 2013). Leaders can fall anywhere on the grid for high-low task, and high-low 
relationship. If a person gets things done, that person would be considered high on the task side of the task/relationship continuum. If one is great at interpersonal relationships, including communication, then you are high on the relationship side of the continuum. Northouse (2013) states that "some research has shown that being high on both task and behaviors is the best form of leadership" (p. 77).

According to the style questionnaire (Northouse, 2013, p. 93), I am on the higher level of both task and relationship, with relationship being higher. In the future, I will need to make sure that I make tasks a priority, particularly the tasks that are less desirable. Knowing my strengths and weaknesses helps me make better decisions and be a better leader. My weakness on the dissertation process was my procrastination and lack of motivation. It was very evident that I was low on the task side of the task/relationship continuum. So far, I categorize my leadership approach to be a combination of trait, skills, and style approaches. This versatility will help me as an educational leader because "different situations call for different types of leadership" (Goleman, 2011).

I see multiple characteristics in the previous styles and approaches within my leadership development, but the one that resonates the most with my value and belief system is servant leadership. Servant leaders are an advocate for social justice and want to help prevent inequalities (Northouse, 2013). Additionally, these types of leaders are sensitive and empathetic by nature and care about others' well-being. Northouse (2013) says that "the norm of caring is more prevalent in non-profit settings" (p. 226).

My career in education aligns with these leadership characteristics. Servant leaders are ethical, and many characteristics of an ethical leader are rooted in Christian values, particularly in the article, Ethical Leadership, by Mihelic, Lipinik, and Tekavcic (2010). Laub (1999) states that valuing people is a key characteristic of servant 
leadership. Valuing people creates an environment of inclusion which promotes diversity. Leaders who value and promote diversity are just better human beings and will treat others in an ethical and respectful manner, while appreciating all different points of view. I feel that this approach will emphasize my strengths and allow me to be true to who I am. Without learning about all types of leadership styles from our assigned reading, I would not have been able to do the leadership or organizational analysis for my dissertation. More importantly, I would not have understood my own leadership style as servant leadership. Understanding and self-awareness go a long way in developing my own leadership skills.

\section{Scholar}

Scholarship and leadership skills are essential components for high quality educators. According to Cambridge Dictionary, a scholar is someone with "great knowledge of a particular subject" (Cambridge Academic Content Dictionary, 2017). I am slowing coming around to the idea that I am a scholar of student engagement as my dissertation topic. The dissertation process has at times made me question whether I could do the scholarly work, as the task was daunting. Additionally, doing the dissertation in a quality manner has given me confidence that I know student engagement well enough not only to improve the student engagement in my classroom, but also help others improve their skills. All these factors have strengthened my skills as a scholar, and in turn, as a leader.

I have learned how to communicate based on evidence (objective), rather than just reporting an opinion (subjective). This was ingrained in me so much that it actually created a problem in my practice between me and a parent. A parent had questioned a decision that I made to speak to her daughter about the dress code. When I responded to 
the parent through email, I quoted the handbook in my email on a definition of something in the dress code to emphasize that I was going by the handbook as my reason for addressing the situation. The parent got offended and angry that I did not think she knew what "such and such" meant by me quoting the handbook. She thought I was insulting her intelligence. I thought I was "citing my source" as reason for my actions and nothing else. Luckily, it blew over after my intentions and apologies for the misunderstanding were more clearly expressed.

A memorable moment when it comes to knowledge gained as a scholar, was driving home for the weekend during the first summer in Columbia and thinking about white privilege. I had not heard of this concept in my 38 years. Why was I not taught about these things, ever? As an educator, part of our responsibility is to promote social justice and equity. I had not been a part of something in which this was emphasized as it was in the ELPA program. I felt like my eyes and brain had been opened. As I began to research my dissertation, I learned more about inequitable situations in education, and began to think about how I could make a difference. This has made me an advocate for social justice and equity in a way that I was not before I started this program. As part of the program, my research and writing skills have improved greatly, giving me the confidence to share with others to further advance scholarship and be an agent of change.

I have learned so many things through this doctoral program - too many to count in this reflection. However, one thing I have learned in both my scholar and leader roles, is organizational analysis. Because my dissertation is a case study of the high school building where I teach, doing the organizational analysis has created a thorough understanding of not only the building in which I work, but the school district. Through this learning process, I have used Bolman and Deal's (2008) Structural Frame, to 
examine the hierarchy of leadership and decision-making processes, as well as Mintzberg's five main parts of an organization (1979/2005).

Through this scholarly practitioner reflection, I have a better understanding of the connections between leadership and scholarship. In addition, I have become more selfaware of my own leadership style and scholarly role, as well as my strengths and weaknesses. I now charge myself with applying the knowledge and experience as a leader and a scholar to improve my organization, presently, and in my future endeavors. 


\section{References}

Bolman, L.G., \& Deal, T.E. (2008). Reframing organizations: Artistry, choice and leadership $\left(4^{\text {th }}\right.$ ed.). San Francisco, CA: Jossey-Bass.

Cambridge Academic Content Dictionary. 2017. Cambridge University Press. Retrieved from http://dictionary.cambridge.org/us/dictionary/english/scholar

Goleman, D. (2011) What makes a leader? In HBR's 10 must reads on leadership (1-22), Boston, Mass: Harvard Business Review Press. (Reprint R0401H, Originally published in June 1996).

Laub, J.A. (1999). Assessing the servant organization: Development of the servant organizational leadership assessment (SOLA) instrument. Dissertation Abstracts International, 60(2), 308. (UMI No. 9921922)

Mihelic, K. K., Lipicnik, B., \& Tekavcic, M. (Fourth Quarter 2010). Ethical leadership. International Journal of Management and Information Systems, 31-41.

Mintzberg, H. (2005). The five basic parts of the organization. In J.M. Shafritz, J.S. Ott \& Y. Jang (Eds.), Classics of organizations theory (6th ed., pp. 219-230). Belmont, CA: Thomson Wadsworth. (Reprinted from The structure of organizations: A synthesis of research, by H. Mintzberg, 1979, Upper Saddle River, NJ: Prentice Hall)

Northouse, P. G. (2013). Leadership: Theory and Practice (6th ed.) Los Angeles, CA: SAGE. 


\section{Appendix}

\section{Interview Questions:}

1. How many years have you been in education? In what capacity?

Teachers only: What general area do you teach (math, science, social studies, etc)?

2. Has your career always been in education or do you bring additional experiences and perspectives from other careers or industries?

3. How would you define student engagement?

4. What factors do you think contribute to student engagement?

5. If someone were to say to you, "those students were really engaged." What kinds of things might the students have been doing or what would that have looked like?

6. On a scale of 1-5, with 1 being the least and 5 being the most, how important do you rate student engagement as it relates to student achievement?

7. How do you know if a student is engaged? Can it be measured? If so, how?

8. Administrators only: What are some pedagogical strategies you have used or observed that increase or maintain high student engagement?

Teachers only: What are some pedagogical strategies you use to increase or maintain high student engagement?

RPDC only: What are some pedagogical strategies that you promote or teach to other teachers that increase or maintain high student engagement?

9. Teachers and Administrators only: Have you had specific training regarding student engagement (for example, Kagan training)? If so, please describe.

RPDC only: What types of student engagement training is offered through the RPDC? 
10. What do you consider obstacles to student engagement?

11. Research shows that often gaps exist between teacher knowledge and experience and what happens or is implemented in the classroom (knowing-doing gap). Do you agree or disagree with this statement as it relates to student engagement and why?

12. Do you think the level of student engagement affects students' attitudes or overall view of education? If so, how? 


\title{
CASE STUDY \\ INFORMED CONSENT
}

\author{
Case Study: \\ I will research teachers' perceptions of student engagement in one rural Midwest high \\ school.
}

\section{Principal investigator:}

Dasha Davis

\section{Institute:}

Northwest Missouri State University

University of Missouri Columbia

\section{Introduction:}

You are invited to participate in an observation or interview to better the understanding of teachers' perceptions of student engagement.

\section{Background information:}

This is research for a dissertation within the Educational Doctorate Program through the University of Missouri- Columbia and Northwest Missouri State University.

\section{Purpose of this research study:}

The purpose of this study is to collect and analyze teachers' thoughts and stories on daily student engagement within their classroom. This study will provide recommendations for the future as to possible best practices when it comes to students being actively involved in their education. Teachers' attitudes, along with the ways they think and learn influence students in the classroom.

This data will provide an opportunity to share and reflect on the many effective ways to engage students. An additional purpose of this research is to help teachers and administrators understand more about how others view and experience student engagement with the desire of meeting (or continuing to meet) the needs of students in a compulsory setting, given all the curriculum standards in the $21^{\text {st }}$ century. The hope of this research is to aid in the reflection process of teachers when preparing, teaching, and adjusting teaching strategies, not just in short-term, but long-term thought processes.

\section{Procedures:}

Interviews: In this study, I will ask questions about each participant's perception regarding student engagement and pedagogical strategies. This interview should take no more than 30 minutes, and will be audiotaped for ease of transcription for the researcher's purpose only.

Observations: The researcher will conduct walk-through observations unannounced for no more than five minutes per class per day with consenting teachers to observe teacher 
interactions, speech, and teaching strategies. With permission, photographs may be taken of educational materials and/or environments.

\section{Possible risks or benefits:}

There is no risk involved in this study except your valuable time. This research has the potential to impact other districts, schools, policy makers, and scholars on their knowledge of educators' views of student engagement.

\section{Right of refusal to participate and withdrawal:}

You are free to choose to participate in the study. You may also withdraw any time from the study. You may also refuse to answer some or all the questions if you do not feel comfortable with the questions.

\section{Confidentiality:}

Any information you provide will remain confidential. No one except the principal investigators will have access to it. Your name and identity will also not be disclosed at any time.

\section{Compensation:}

One $\$ 10$ gift card of the subject's choice will be provided as compensation for the subject's time to participate in this research.

\section{Available Sources of Information:}

If you have questions please contact me at dashadavis2013@gmail.com or at 816-2626331. For further questions, you may contact Northwest Missouri State University Professor, Dr. Carole Edmonds (cake@,nwmissouri.edu), the researcher's advisor.

\section{AUTHORIZATION}

I have read and understand this consent form, and I volunteer to participate in this research study. I understand that I will receive a copy of this form. I voluntarily choose to participate, but I understand that my consent does not take away any legal rights in the case of negligence or other legal fault of anyone who is involved in this study. I further understand that nothing in this consent form is intended to replace any applicable Federal, state, or local laws.

If you have any further questions I can answer, please contact me.

Dasha Davis

103 W. Elk St.

Savannah, MO 64485

816-262-6331 dashadavis2013@gmail.com

You may also contact the Campus Institutional Review Board if you have questions about your rights, concerns, complaints or comments as a research participant. You can contact the Campus Institutional Review Board directly by telephone or email to voice or 
solicit any concerns, questions, input or complaints about the research study.

483 McReynolds Hall Columbia, MO 65211 573-882-9585 E-Mail:

umcresearchcirb@missouri.edu Website:

http://www.research.missouri.edu/cirb/index.htm

\section{CONSENT TO BE AUDIO-RECORDED DURING THE INTERVIEW}

I consent to be audio-recorded during the approximately 30 -minute interview. I understand I can decline to be recorded at any time.

(Audio-recorded consent adapted from the U.S. Department of Human services, 1998, Informed Consent Checklist) 


\section{References}

Alumni Association (2017). Nateville High School. Retrieved from http://.nhsalumni.net/nhs_history.asp

Amabile, T. (1981, April). Brilliant but cruel: Perceptions of negative evaluators. Paper presented at the annual meeting of the Eastern Psychological Association. New York, NY. Retrieved from ERIC database.

Antaramian, S.P., Huebner, E.S., Hills, K.J., \& Valois, R.F. (2010). A dual-factor model of mental health: Toward a more comprehensive understanding of youth functioning. American Journal of Orthopsychiatry, 80(4), 462-472.

Appleton, J. J., Christenson, S. L., Kim, D., \& Reschly, A. L. (2006). Measuring cognitive and psychological engagement: Validation of the student engagement instrument. Journal of School Psychology, 44, 427-445.

doi:10.1016/j.jsp.2006.04.002

Auken, P.V. (2012). Maybe it's both of us: Engagement and learning. Teaching Sociology. Sage Publications. 41 (2), 207-215. doi:10.1177/0092055x12457959

Bolman, L. G., \& Deal. T. E. (2008). Reframing organizations: Artistry, choice, and leadership ( $4^{\text {th }}$ ed.). San Francisco, CA: Jossey-Bass.

Brint, S., Cantwell, A. M., \& Hanneman, R. A. (2008). The two cultures of undergraduate academic engagement. Research in Higher Education, 49(5), 383402. doi:10.1007/s11162-008-9090-y

Cambridge Academic Content Dictionary. 2017. Cambridge University Press. Retrieved from http://dictionary.cambridge.org/us/dictionary/english/scholar 
Carini, R.M., Kuh, G.D., \& Klein, S.P. (2006). Student engagement and student learning: Testing the linkages. Research in Higher Education, 47(1), 1-32. doi:10.1007/s11162-005-8150-9

Caskey, M. M., \& Ruben, B. (2003). Research for awakening adolescent learning. The Education Digest, 36-38.

Check \& Connect Student Engagement Intervention. (2016). Emphasis on student engagement. Retrieved from University of Minnesota, Institute on Community Integration. http://checkandconnect.umn.edu/model/engagement.html

Corso, M. J., Bundick, M.J., Quaglia, R. J., \& Haywood, D. E. (2013). Where student, teacher, and content meet: Student engagement in the secondary school classroom. American Secondary Education, 41(3), 50-61.

Creswell, J.W. (2014). Research design: Qualitative, quantitative, and mixed methods approaches. Los Angeles, CA: Sage.

Crotty, J.M. (2013, March). Motivation matters: 40\% of high school students chronically disengaged from school. Retrieved from https://www.forbes.com/sites /jamesmarshallcrotty/2013/03/13/motivation-matters-40-of-high-school-studentschronically-disengaged-from-school/\#3b5ddad06594

District Directory (2016). Nateville School District. Retrieved from http://natevillehs.com /UserFiles/Servers/Server_227053/File/Our\%20District/Staff\%20Directory/Distri ct\%20Directory\%202016.pdf

District Report Card (2017). Missouri comprehensive data system. Missouri Department of Elementary and Secondary Education. Retrieved from https://mcds.dese.mo. gov/guidedinquiry/School 
Doidge, N. (2007). The brain that changes itself: Stories of personal triumph from the frontiers of brain science. New York, NY: Penguin Books.

Donnelly, M. (1987). At-risk students. ERIC digest. Eugene, OR: ERIC Clearinghouse on Educational Management. (ERIC Id. ED292171)

Dufour, R., \& Marzano, R.J. (2011). Leaders of learning: How district, school, and classroom leaders improve student achievement. Bloomington, IN: Solution Tree press.

Eccles, J.S., \& Wigfield, A. (2002). Motivational beliefs, values, and goals. Annual Review of Psychology, 53, 109-132.

Economos, J. (2014). The squeaky wheel needs the Grease: Perceptions of teaching and learning in graduate education. The Journal of Effective Teaching, 14(1), 5-19.

Elbaz, F. (1981). The teacher's "practical knowledge": Report on a case study. Curriculum Inquiry, 11(1), 43-71.

Eldridge, J.S. (1998). Searching for meaning: Reflections on meaningful professional development. Curriculum Inquiry, 28(4), 491-502.

Emerson, R.M., Fretz, R.I., \& Shaw, L.L. (2011). Writing ethnographic fieldnotes. $\left(2^{\text {nd }}\right.$ ed.). Chicago, IL: The University of Chicago Press.

Erickson, G., Brandes, G.M., Mitchell, I., \& Mitchell, J. (2005). Collaborative teacher learning: Findings from two professional development projects. Teaching and Teacher Education, 21, 787-798.

Fink, A. (2013). How to conduct surveys: A step-by-step guide (5th ed.) Thousand Oaks, CA: SAGE.

Forneris, T., Camiré, M., \& Williamson, R. (2015). Extracurricular activity participation and the acquisition of developmental assets: Differences between involved and 
noninvolved Canadian high school students. Applied Developmental Science 19(1), 47-55. Doi:10.1080/10888691.2014.980580

Fullan, M. (1993). Change forces: Probing the depths of educational reform. Levittown, PA: The Falmer Press.

Garcia, I. A., \& Pacheco, C. L. (2010). Constructivism in Mexican elementary school education: Designing a platform for cooperative learning. Journal of Software, $5(6), 565-572$.

Gardner, D. P., And Others. (1983). A nation at risk: The imperative for educational reform. Report prepared for National Commission in Education. Retrieved from Government Printing Office website:

http://files.eric.ed.gov/fulltext/ED226006.pdf

Genç, M. (2016). An evaluation of the cooperative learning process by sixth-grade students. Research in Education, 95(1), 19-32.

Gentilucci, J.L. (2004). Improving school learning: The student perspective. The Educational Forum, 68, 133-143.

Gill, S. (2010). Developing a learning culture in nonprofit organizations. Los Angeles, CA: SAGE.

Goleman, D. (2011) What makes a leader? In HBR's 10 must reads on leadership (1-22), Boston, Mass: Harvard Business Review Press. (Reprint R0401H, Originally published in June 1996).

Hall, J. (2016, September 16). Nateville school district receives $\$ 1$ million to build new preschool. St. Joseph News-Press. Retrieved from http://www.newspressnow.com 
Hamady, C. M., Ludy, M., Anderson, D. L., \& El-Khechen, N. H. (2014). Using twitter to enhance engagement in undergraduate nutrition courses. Journal of the Academy of Nutrition and Dietetics, 114(9), A67.

Harris, L. (2011). Secondary teachers' conceptions of student engagement: Engagement in learning or in schooling? Teaching and Teacher Education, 27, 376-386.

Hopkins, C. (2013). Educating for Sustainability: An emerging purpose of education, Kappa Delta Pi Record, 49(3), 122-125, doi: 10.1080/00228958.2013.819193

Intervention, (2014). Institute on Community Integration. Retrieved from University of Minnesota: http://checkandconnect.umn.edu/

Jackling, B., \& Natoli, R. (2011). Student engagement and departure intention: An Australian university perspective. Journal of Further and Higher Education, 35, 561-579. doi:10.1080/0309877x.2011.584970

Key to America's global competitiveness: A quality education: Hearing before the Committee on Health, Education, Labor, and Pensions, Senate, $112^{\text {th }}$ Cong. (2012).

Kidwell, C. (2010). The impact of student engagement on learning. Leadership, Mar/Apr, 28-31.

Kimmelman, P. (2006). Implementing NCLB: Creating a knowledge framework to support school improvement. Thousand Oaks, CA: Corwin Press.

Klem, A.M., \& Connell, J.P. (2004). Relationships matter: Linking teacher support to student engagement and achievement. Journal of School Health. 74(7) 262-272.

Knowles, M. (1950). Informal adult education. New York, NY: Association Press.

Kohn, A. (1987). The case against competition. Retrieved from http://www.alfiekohn.org /article/case-competition/ 
Krueger, R. A., \& Casey, M. A. (2009). Focus groups: A practical guide for applied research. Thousand Oak, CA: SAGE.

Kuh, G.D. (2001). Assessing what really matters to student learning inside the national survey of student engagement. Change: The Magazine of Higher Learning, 33(3), 10-17. doi: 10.1080/00091380109601795

Kuh, G.D. (2009). What student affairs professionals need to know about student engagement. Journal of College Student Development. 50(6), 683-706. doi: 10.1353/csd.0.0099

Laub, J.A. (1999). Assessing the servant organization: Development of the servant organizational leadership assessment (SOLA) instrument. Dissertation Abstracts International, 60(2), 308. (UMI No. 9921922)

Layton, L. (2014, April 28). National high school graduation rates at historic high, but disparities still exist. The Washington Post. Retrieved from http://www.washingtonpost.com

Lee, J., \& Shute, V. (2009). The influence of noncognitive domains on academic achievement in K-12 (ETS Research Rep. No. RR-09-34). Princeton, NJ: ETS

Longenecker, R. N. (1982). The pedagogical nature of the law in Galatians 3:194:7, Journal of the Evangelical Theological Society, 25(1), 53-61.

Long-Range Facilities Plan. (2006). Nateville School District. Retrieved from http://nateville.schoolwires.net/cms/lib6/MO01001842/ Centricity /Domain/28/Long\%20Range\%20Facilities\%20Plan.pdf

Laub, J.A. (1999). Assessing the servant organization: Development of the servant organizational leadership assessment (SOLA) instrument. Dissertation Abstracts International, 60(2), 308. (UMI No. 9921922) 
McCarthy, M., Kuh, G.D. (2006). Are students ready for college? What student engagement data say. The Phi Delta Kappan, 87(9), 664-669.

McGregor, D. M. (2005). The human side of enterprise. In J.M. Shafritz, J.S. Ott \& Y. Jang (Eds.), Classics of organizations theory (6th ed., pp. 179-184). Belmont, CA: Thomson Wadsworth. (Reprinted from Management Review by D.M. McGregor, 1957, New York: American Management Association)

Merriam, S. B. (2009). Qualitative research: A guide to design and implementation. Hoboken, NJ: Jossey-Bass.

Merriam, S. B., \& Bierema, L.L. (2014). Adult learning: Linking theory and practice. San Francisco, CA: Jossey-Bass.

Mihelic, K. K., Lipicnik, B., \& Tekavcic, M. (Fourth Quarter 2010). Ethical leadership. International Journal of Management and Information Systems, 31-41.

Mintzberg, H. (2005). The five basic parts of the organization. In J.M. Shafritz, J.S. Ott \& Y. Jang (Eds.), Classics of organizations theory (6th ed., pp. 219-230). Belmont, CA: Thomson Wadsworth. (Reprinted from The structure of organizations: A synthesis of research, by H. Mintzberg, 1979, Upper Saddle River, NJ: Prentice Hall)

Missouri Department of Elementary and Secondary Education. (n.d.). Missouri's Educator Evaluation System. Retrieved April 1, 2017, from https://dese.mo.gov/sites/default/files/00-TeacherEvaluation-CompleteDoc.pdf Mitchell, I., \& Carbone, A. (2011). A typology of task characteristics and their effects on student engagement. International Journal of Educational Research, 50, 257-270. doi: 10.1016/j.ijer.2011.05.001 
Mitchell, J. (2000). P.A.V.O.T. - The perspective and voice of the teacher. Peel Seeds, 50.

Monroe, P.M. (1912). A brief course on the history of education. New York, NY: MacMillian. Retrieved from https://archive.org/stream/briefcourseinhis 00 monruoft\#page/314/mode/2up

Myungjoon, L. (1994). Plato's philosophy of education: Its implication for current education (Doctoral dissertation). Available from Proquest Digital Dissertations database. Retrieved from http://epublications.marquette.edu/dissertations/ AAI9517932

Nateville High School. (n.d.). District mission statement. Retrieved from http:/hs.nateville.com/

Nateville School District. (2015, September). Board strategic priorities/goals/action steps. Retrieved from http://www.nateville.com/UserFiles/Servers/Server_227053/File /Nateville/District/Documents/Board\%20of\%20Education/Goals\%20updated\%20 September\%203.pdf

National Conference of State Legislatures. (2017). National unemployment monthly update. Retrieved from http://www.ncsl.org/research/labor-andemployment/national-employment-monthly-update.aspx

National Research Council and Institute of Medicine. (2004). Engaging schools: Fostering high school students' motivation to learn. Washington, DC: The National Academies Press.

Newmann, F.M. (Ed.). (1992). Student engagement and achievement in American secondary schools. New York, NY: Teachers College Press.

Northouse, P. G. (2013). Leadership: Theory and practice. Los Angeles, CA: SAGE. 
OECD (2016), Reading performance (PISA) (indicator). doi: 10.1787/79913c69-en

Ozdemir, M., \& Kalayci, H. (2013). An examination on school engagement and metaphorical school perception: Case of province of Cankiri. Educational Sciences: Theory \& Practice, 13(4), 2134-2137. doi:10.12738/estp.2013.4.1680

Pfeffer, J., \& Sutton, R. I. (2000). The knowing-doing gap: How smart companies turn knowledge into action. Boston, MA: HARVARD BUSINESS SCHOOL PRESS.

Pfeffer, J., \& Salancik, G.R. (2005). External control of organizations: A resource dependence perspective. In J.M. Shafritz, J.S. Ott \& Y. Jang (Eds.), Classics of organizations theory (6th ed., pp. 521-532). Belmont, CA: Thomson Wadsworth. (Reprinted from The external control of organizations, by J. Pfeffer and G.R. Salancik, 1978, New York: Harper \& Row)

Race to the Top Act of 2013, H.R. 426, $113^{\text {th }}$ Cong. (2013).

Ritchhart, R., Church, M., \& Morrison, K. (2011). Making thinking visible: How to promote engagement, understanding, and independence for all learners. San Francisco, CA: Jossey-Bass.

Rumberger, R.W. (2013). Poverty and high school dropouts: The impact of family and community poverty on high school dropouts. American Psychological Association. Retrieved from http://www.apa.org/pi/ses/resources/indicator /2013/05/ poverty-dropouts.aspx

Senate Rep. No. 83-915, at 2 (1972).

Smagorinsky, P., Wright, L., Augustine, S., O’Donnell-Allen, C., \& Konopak, B. (2007). Student engagement in the teaching and learning of grammar: A case study of an early-career secondary school English teacher. Journal of Teacher Education, 58(1), 76-90. doi: 10.1177/0022487106295727 
Smith, M. K. (2012). What is pedagogy? Retrieved from http://infed.org/mobi/what-ispedagogy/

Sousa, D. A. (2011). How the brain learns. Thousand Oaks, CA: Corwin.

Sparks, D. (2009). Reach for the heart as well as the mind. JSD, 30(1), 48-54.

Sperling's Best Places. (2017). Info on cost of living, schools, crime rates, house prices, and more... Retrieved from http://www.bestplaces.net/city/missouri/savannah

Thornberry, T., Moore, M., \& Christenson, R. (1985). The effect of dropping out of high school on subsequent criminal behavior. Criminology 23(1), 3-18.

Tileston, D.W. (2011). 10 Best teaching practices: How brain research and learning styles define teaching competencies. Thousand Oaks, CA: Corwin.

Tinto, V. (1987). The principles of effective retention. Paper presented at the Fall Conference of the Maryland College Personnel Association. Largo: Viewpoints. Retrieved August 6, 2015

Torpey, E., \& Watson, A. (2014, September). Education level and jobs: Opportunities by state. Bureau of Labor Statistics. Retrieved from https://www.bls.gov/_career outlook/2014/article/education-level-and-jobs.htm

U. S. Census Bureau. (2010). State \& county quickfacts: Allegany County, N.Y. Retrieved from https:// www.census.gov/quickfacts/ table/ PST045216/29003,00

U. S. Department of Education. (2003). No child left behind: A toolkit for teachers. Office of the Under Secretary. Washington, D.C.

U. S. Department of Education. (2015). Fast facts. National Center for Education Statistics. Retrieved from https://nces.ed.gov/fastfacts/display.asp?id=16 U. S. Department of Education (2015). Elementary and Secondary Education Act. Retrieved from http://www.ed.gov/esea 
Valentine, J. (2005). Instructional practices inventory: A process for profiling student engaged learning for school improvement. Middle Level Leadership Center. University of Missouri. Retrieved from http://mllc.missouri.edu/Upload\%20AreaDocs/IPI\%20Manuscript\%208-05.pdf

Valentine, J. (2009). Evidence re the importance of engagement. Pdf. Copy in possession of researcher.

Willms, J.D., Friesen, S. \& Milton, P. (2009). What did you do in school today?

Transforming classrooms through social, academic and intellectual engagement. (First National Report) Toronto: Canadian Education Association. Retrieved from ERIC database.

Zhang, Z., Hu, W., \& McNamara, O. (2015). Undergraduate student engagement at a Chinese university: A case study. Educational Assessment, Evaluation and Accountability, 27(2), 105-127. doi:10.1007/s11092-015-9213-x

Zheltoukhova, K. (2014). Leadership in organizational practice: Closing the knowingdoing gap. Strategic HR Review, 13(2), 69-74. doi: 10.1108/SHR-10-2013-0093

Zyngier, D. (2008). (Re)conceptualizing student engagement: Doing education not doing time. Teaching and Teacher Education, 24, 1765-1776. doi:

10.1016/j.tate.2007.09.004

Zyngier, D. (2011). Raising engagement and enhancing learning: School community partnerships that work for students at Promise. Creative Education. 2(4), 375-380. doi:10.4236/ce.2011.24053 
The author of this research, Dasha Davis, has lived in Missouri since age 2 years old. Dasha attend several public schools in Northwest Missouri, graduating valedictorian from Albany High School. Dasha attended Missouri Western State College (now University), and double majored in Business Management and Spanish.

Upon completion of her undergraduate degree, Dasha worked for the U.S. Postal Service in various positions - clerk, on-the-job trainer, acting supervisor, associate supervisor, and supervisor of customer services. After four years at the Postal Service, she changed careers to pursue what she felt was a higher calling. She began teaching high school Spanish at Mount Saint Scholastica Academy in Atchison, Kansas, an all-girls Catholic international boarding school (now Maur Hill - Mount Academy). After four years there, Dasha started teaching Spanish at Savannah R3 High School in Savannah, Missouri while completing an alternative teaching certification program at Northwest Missouri State University.

Dasha completed a Master's degree in Liberal Arts from Baker University. In December of 2012, Dasha was accepted into the state-wide doctorate program in Educational Leadership and Policy Analysis through the University of Missouri Columbia and graduated in the summer of 2017. Dasha continues to think that she was called to be a teacher, as she tries to educate, inspire, and encourage young people daily. 